\title{
The Dallol Geothermal Area, Northern Afar (Ethiopia) -An Exceptional Planetary Field Analog on Earth
}

\author{
B. Cavalazzi, ${ }^{1,2}$ R. Barbieri, ${ }^{1}$ F. Gómez, ${ }^{3}$ B. Capaccioni, ${ }^{1, *}$ K. Olsson-Francis, ${ }^{4}$ M. Pondrelli, ${ }^{5}$ A.P. Rossi, ${ }^{6}$ \\ K. Hickman-Lewis, ${ }^{1,7}$ A. Agangi, ${ }^{2}$ G. Gasparotto, ${ }^{1}$ M. Glamoclija, ${ }^{8}$ G. G. Ori, ${ }^{5}$ N. Rodriguez, ${ }^{3}$ and M. Hagos ${ }^{9}$
}

\begin{abstract}
The Dallol volcano and its associated hydrothermal field are located in a remote area of the northern Danakil Depression in Ethiopia, a region only recently appraised after decades of inaccessibility due to severe political instability and the absence of infrastructure. The region is notable for hosting environments at the very edge of natural physical-chemical extremities. It is surrounded by a wide, hyperarid salt plain and is one of the hottest (average annual temperature Dallol $: 36-38^{\circ} \mathrm{C}$ ) and most acidic natural systems $\left(\mathrm{pH}_{\text {Dallol }} \approx 0\right.$ ) on Earth. Spectacular geomorphologies and mineral deposits produced by supersaturated hydrothermal waters and brines are the result of complex interactions between active and inactive hydrothermal alteration of the bedrock, sulfuric hot springs and pools, fumaroles and geysers, and recrystallization processes driven by hydrothermal waters, degassing, and rapid evaporation.

The study of planetary field analog environments plays a crucial role in characterizing the physical and chemical boundaries within which life can exist on Earth and other planets. It is essential for the definition and assessment of the conditions of habitability on other planets, including the possibility for biosignature preservation and in situ testing of technologies for life detection. The Dallol area represents an excellent Mars analog environment given that the active volcanic environment, the associated diffuse hydrothermalism and hydrothermal alteration, and the vast acidic sulfate deposits are reminiscent of past hydrothermal activity on Mars. The work presented in this paper is an overview of the Dallol volcanic area and its hydrothermal field that integrates previous literature with observations and results obtained from field surveys and monitoring coupled with sample characterization. In so doing, we highlight its exceptional potential as a planetary field analog as well as a site for future astrobiological and exploration programs. Key Words: Hydrothermal systems-Extreme environments-Polyextremophiles-East Africa-Terrestrial analogs-Astrobiology-Planetary science. Astrobiology 19, 553-578.
\end{abstract}

\section{Table of Contents}

1. Introduction $\quad 554$

2. Geological Setting

3. The Danakil Depression and the Dallol Geothermal Area 558

3.1. Dallol geothermal area: stratigraphic and minero-petrographic features 560

${ }^{1}$ Dipartimento di Scienze Biologiche, Geologiche e Ambientali, Università di Bologna, Bologna, Italy.

${ }^{2}$ Department of Geology, University of Johannesburg, Johannesburg, South Africa.

${ }^{3}$ Centro de Astrobiologia and Instituto Nacional de Técnica Aeroespacial, Madrid, Spain.

${ }^{4}$ School of Environment, Earth and Ecosystem Sciences, The Open University, Milton Keynes, United Kingdom.

${ }^{5}$ Int'l Research School of Planetary Sciences, Università d'Annunzio, Chieti Scalo, Italy.

${ }^{6}$ Jocobs University, Bremen, Germany.

${ }^{7}$ CNRS Centre de Biophysique Moléculaire, Orléans, France.

${ }_{9}^{8}$ Department of Earth and Environmental Sciences, Rutgers University, Newark, New Jersey, USA.

${ }^{9}$ Department of Earth Sciences, Mekelle University, Mekelle, Ethiopia.

* Deceased September 9, 2016.

(C) B. Cavalazzi et al., 2018; Published by Mary Ann Liebert, Inc. This Open Access article is distributed under the terms of the Creative Commons Attribution Noncommercial License (http://creativecommons.org/licenses/by-nc/4.0/) which permits any noncommercial use, distribution, and reproduction in any medium, provided the original author(s) and the source are credited. 
3.2. Dallol geothermal area: the hot springs 561

3.2.1. Water geochemistry 561

3.2.2. Mounds, geysers, pools, and terraces $\quad 562$

3.2.3. Salt mushroom- and artichoke-like structures 565

3.2.4. Salt rims

3.2.5. Climate and vegetation $\quad 566$

4. Dallol Geothermal Field in an Astrobiological Perspective 568

4.1. Relevance of hydrothermal systems in astrobiology 569

4.2. Extremophiles of geothermal systems 570

4.2.1. High-temperature environments and (hyper)thermophiles 571

4.2.2. Acidic environments and acidophiles 571

4.2.3. Salt environments and halophiles 571

4.2.4. Polyextremophiles 571

4.3. Terrestrial analogs for Mars science 572

5. Conclusions 573

Authors' Note 574

Acknowledgments $\quad 574$

References 574

\section{Introduction}

$\mathbf{P}$ ROGRESS MADE in recent decades in the understanding of geological and biological planetary processes and their coevolution has shown that life may exist, and could have originated, in almost all the extreme environments that were considered detrimental to life in the recent past (e.g., Brock, 1967; Rothschild and Mancinelli, 2001; Martin et al., 2008).

Presently, microorganisms can be found in most natural and artificial (e.g., acid mine drainage) extreme environments where liquid water and metabolically suitable carbon, energy, and nutrient sources exist. Living organisms tend to be sensitive to drastic changes in their environment, and their cellular integrity may be seriously compromised in extreme physical (e.g., temperature, desiccation, radiation, and pressure) and (geo-)chemical (e.g., salinity, $\mathrm{pH}$, redox potential, or heavy metals) conditions. The microorganisms that live in the presence of such challenges are termed extremophiles and have physiologically adapted to live in and/ or survive or tolerate these extreme and adverse environmental conditions.

The diversity and versatility of microbial metabolism combined with the extraordinary physiological capacities of many microorganisms to colonize any habitat suggest that a number of unrecognized terrestrial habitats probably exist. By analogy, this could also be true for other planetary bodies. Therefore, studying geological processes in extreme environments, together with habitability, plays a crucial role in determining the physical and chemical boundaries within which life can exist on Earth. In the comprehension of planetary landforms, in the assessment and definition of the criteria for habitability on other planets including the possibility for biosignature preservation (in their host matrix), for in situ testing of technologies and methodologies (e.g., rovers and their payload), and for verifying laboratory methods and protocols for life-detection, such an approach provides valuable and critical information for future space missions (Amils et al., 2007a; Baker, 2014; Martins et al., 2017; Vago, 2017; Cavalazzi and Westall, 2019).

The Danakil (or Danakhil) Depression in the northern part of the Afar Depression (also known as the Afar Triangle)
(Figs. 1 and 2), with its variety of extreme environmental conditions, intense seismicity, volcanism and associated hydrothermal activities, intermittent water flooding and sedimentary processes, is well known to geoscientists-for example, structural geologists, geophysicists, and volcanologists - as being part of the East African Rift System (Corti, 2009), an active continental rift system deforming a wide area between Djibouti and Mozambique (e.g., McKenzie et al., 1970; Ebinger and Casey, 2001; Tesfaye et al., 2003; Beyene and Abdelsalam, 2005). It is also known for its (as yet not comprehensively estimated) natural resources that mostly comprise salt rocks such as potash, sulfur, manganese, bentonite, gold, and light and heavy hydrocarbon deposits, and for its promising geothermal energy sources (Allana Potash Corporation, 2011, 2012; Warren, 2016; Varet, 2018). The region is widely renowned among palaeoanthropologists due to its early hominid fossil finds including "Lucy," the Australopithecus afarensis specimen discovered in 1974, dated at between 3.9 and 2.9 million years old (e.g., Wood, 1994), and early human habitats. The Afar Region, in which a 4.4-million-year-old hominid named "Ardi" (Ardipithecus ramidus) was also discovered (White et al., 1994), can be considered the place of origin of humankind. Finally, the region has been recently identified by astrobiologists as hosting the most diverse suite of extreme environments on Earth (Cavalazzi et al., 2014).

Herein, we present (1) an updated overview of the Dallol (also rarely spelled Dalol) geothermal area, which is located in the Danakil Depression of the administrative Zone Two of the Afar National Regional State, in the northern part of Ethiopia (Fig. 1), integrating data from literature with observations and results obtained from field surveys and laboratory analysis, and (2) the enormous potential of the main site of the Dallol hot springs as a planetary field analog environment, highlighting its potential for astrobiological research. We also provide a brief examination of current advances concerning our understanding of the temperature-, $\mathrm{pH}$ - and salinity-resistant extremophilic microbes and their mechanisms of adaptation, and of the exploration of some examples of the extreme environmental conditions on Earth in which they are found. 


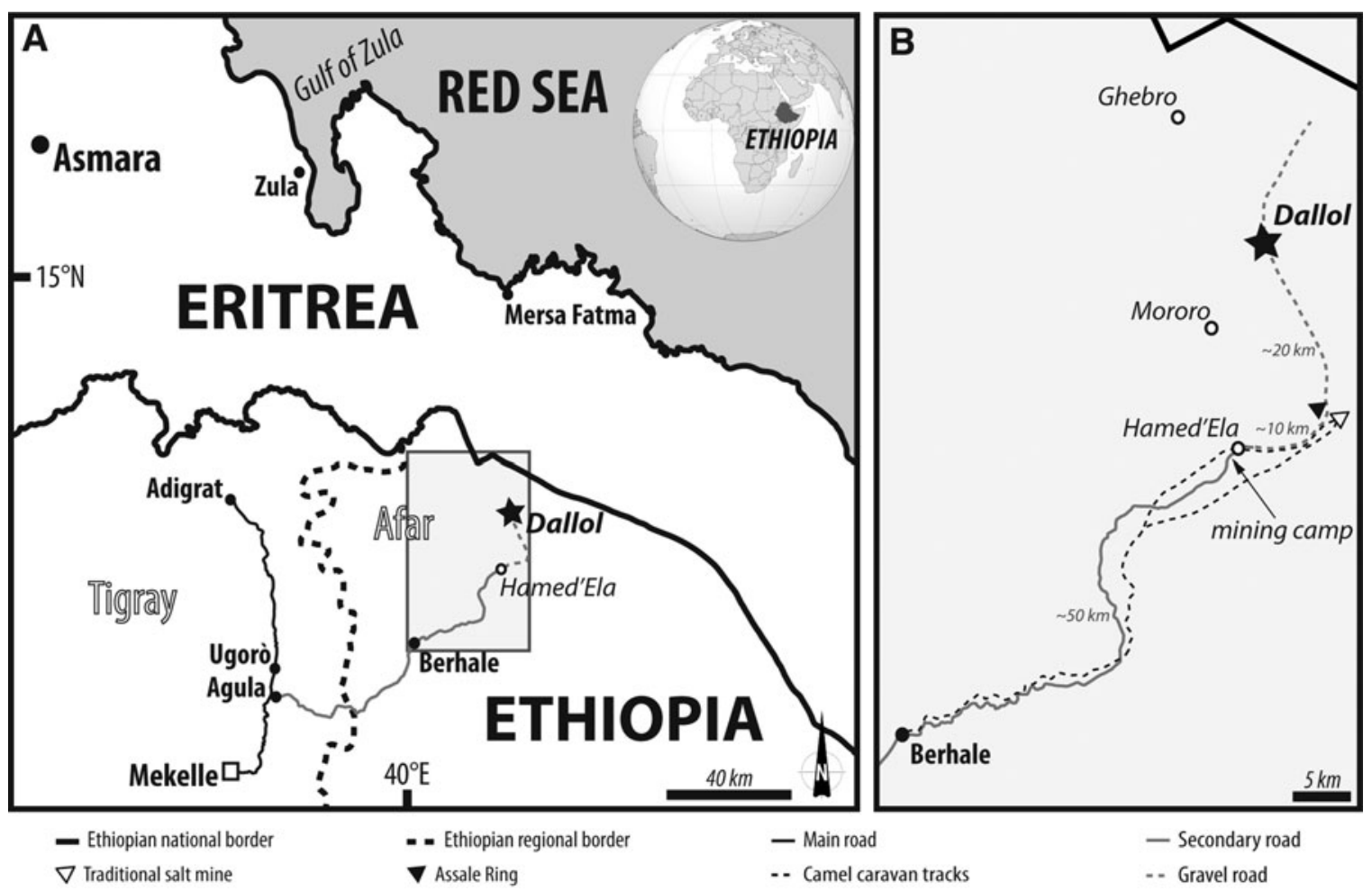

FIG. 1. Location map of the study area. (A) The Dallol volcano is located in the northern part of the Afar Region in Ethiopia (black star; $\left.14^{\circ} 05^{\prime} 28.00^{\prime \prime} \mathrm{N}, 40^{\circ} 17^{\prime} 58.00^{\prime \prime} \mathrm{E}\right)$. (B) Detail of the boxed area in (A) showing the directions of roads and tracks from the town of Berhale $\left(13^{\circ} 51^{\prime} 46^{\prime \prime} \mathrm{N}, 40^{\circ} 01^{\prime} 19.40^{\prime \prime} \mathrm{E}\right.$; $67 \mathrm{~m}$ a.s.1.) to the village of Hamed'Ela $\left(14^{\circ} 05^{\prime} 06.00^{\prime \prime} \mathrm{N}\right.$, $40^{\circ} 16^{\prime} 46.00^{\prime \prime} \mathrm{E}$; $90 \mathrm{~m}$ b.s.l.) in the direction of the Dallol geothermal area. The Assale (or As'Ale, or Ashale) Ring $\left(14^{\circ} 7^{\prime} 0.63 \mathrm{~N} ., 40^{\circ} 20^{\prime} 52.59 \mathrm{E}\right)$, also known as Skating Ring, is a $\sim 20 \mathrm{~m}$ high ring-structure, generated by a phreatic explosion, of reddish-gray evaporites and mud mixtures with a diameter of $\sim 110 \mathrm{~m}$ which rises $\sim 15 \mathrm{~km}$ south of the Dallol volcanic dome. The evaporites from Assale Ring, considered sacred by Afars, are used as traditional medicine.

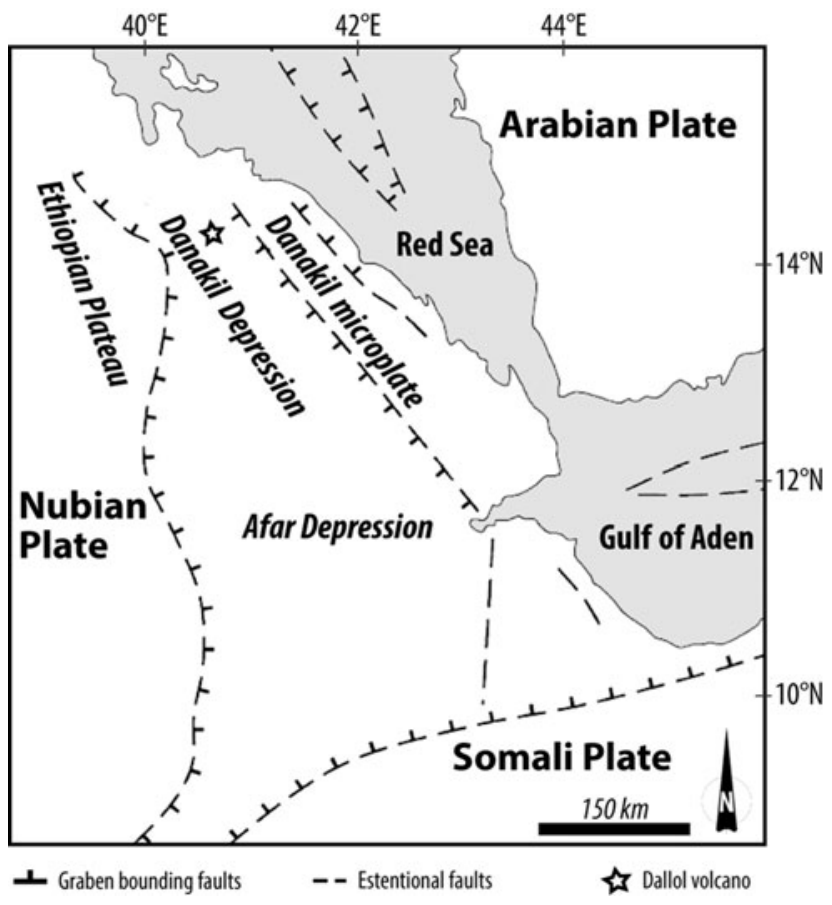

FIG. 2. Simplified tectonic map of the triangular-shaped Afar Depression. The Dallol volcano (star) is located in the northern part of the Danakil Depression. Adapted from Tesfaye et al. (2003).

\section{Geological Setting}

The Dallol geothermal area is part of the Danakil Depression, which straddles the Ethiopia-Eritrea border, between the Ethiopian Plateau and the Danakil microplate (also called Danakil Alps or Mountains) in the northern part of the Afar Depression (Figs. 1 and 2).

The Afar Depression is an incipient seafloor-spreading center located at the triple junction between the Nubian, Somali, and Arabian plates, atop the developing Danakil microplate that is generating the continental breakup of Africa (e.g., McKenzie et al., 1970; Barberi et al., 1972; Ebinger and Casey, 2001; Tesfaye et al., 2003; Acocella, 2010; McClusky et al., 2010) (Figs. 2 and 3). Here, the E-W ocean ridge spreading of the Gulf of Aden through Djibouti meets the axes of the Ethiopian Rift and the Red Sea (Fig. 3). McClusky et al. (2010) reported spreading rates of $\sim 7 \mathrm{~mm} /$ year at the northern edge of the Afar Depression.

The Danakil Depression in the northern tectono-magmatic domains of the Afar Depression is a well-defined tectonic feature bordered both to the west and to the east by major faults and dissected escarpments (Figs. 2 and 3; Tesfaye et al., 2003). The attenuated continental crust has a thickness of $<15 \mathrm{~km}$ with shallow (3-5 km deep) magma chambers beneath its axial zones (Makris and Ginzburg, 1987; Maguire et al., 2006; Wright et al., 2006; Pagli et al., 2012). The main volcano-tectonic features of these magmatic segments are intermittent NNW-SSE axial volcanic edifices and fissure 


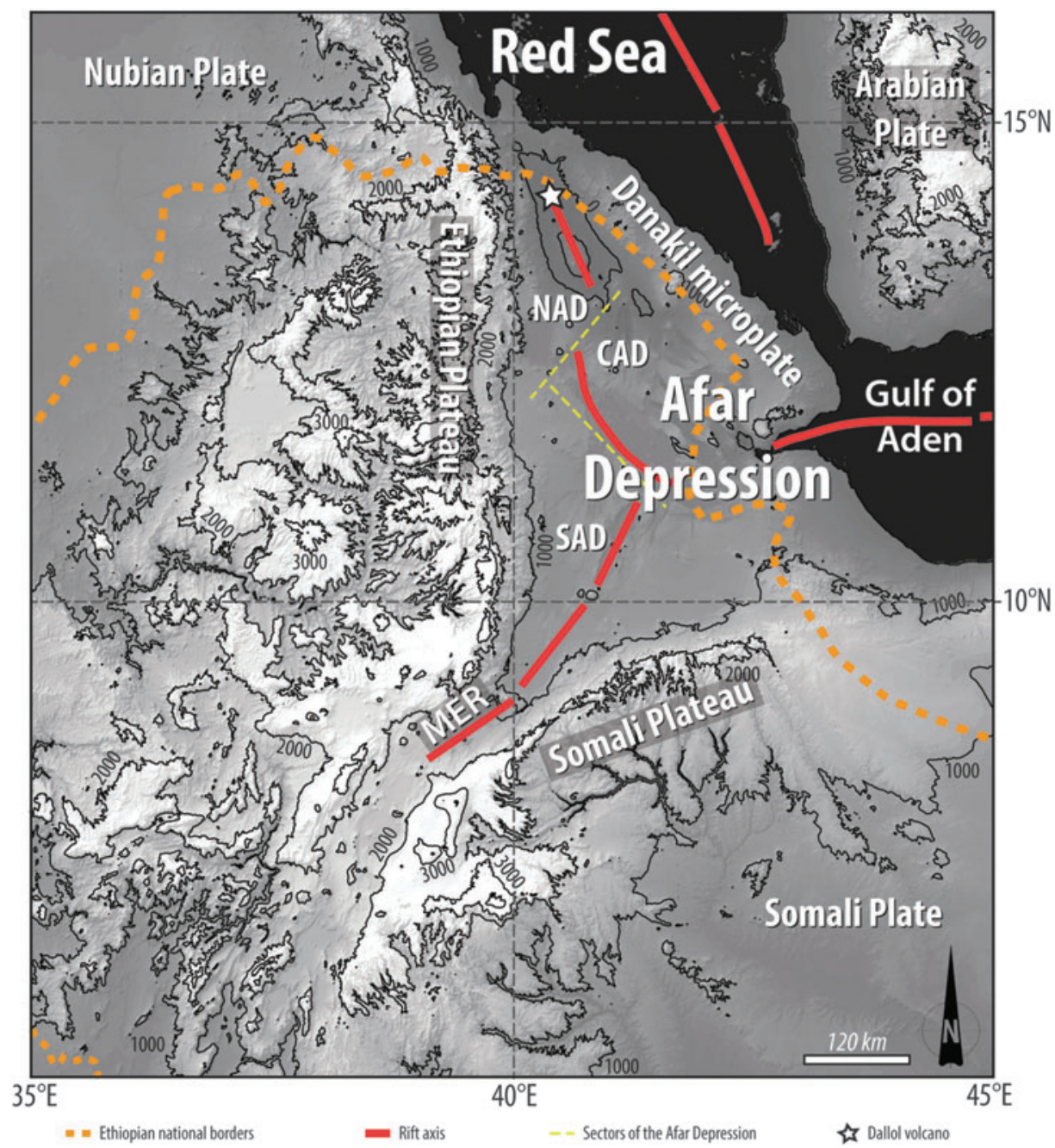

FIG. 3. Digital elevation map (SRTM data) of the Afar Depression, together with the Red Sea, Gulf of Aden, and Main Ethiopian (MER) rift zones (red lines) splitting apart the Arabian, Nubian, and Somali plates. NAD, CAD, SAD (separated by the yellow broken lines) are the northern, central and southern sectors of the Afar Depression (see Tesfaye et al., 2003). The Dallol volcano (star) lies between the Danakil microplate and the Ethiopian plateau.

basalts, open extensional fractures and vertical step faulting (Figs. 4 and 5). The volcanic activity in this region has been intense since the Pliocene but is today mostly restricted to the axial zone with the spectacular shield and stratovolcanoes of the Erta' Ale Range (in the Afar language, 'Ale means mount), which include Ale Bagu, Erta'Ale, Borale'Ale, Dalafilla Alu, and other small volcanic and fumarolic centers (Barberi and Varet, 1971; Barrat et al., 1998; Acocella, 2006; Ebinger et al., 2008). Of the volcanic edifices that constitute the Erta'Ale Range, the Gada'Ale shield volcano and its surrounding fissural eruptions are part of the Dallol area (Fig. 4).

The magmatic and tectonic activity of the shield volcanoes of the Erta'Ale Range extends (NNW-SSE) to the Dallol area, and probably to the Gulf of Zula, as a continuous trending rift branch (Thurmond et al., 2006). Satellite remote sensing and seismicity analyses have revealed the presence of a shallow dyke intrusion $\left(\sim 0.06 \mathrm{~km}^{3}\right)$ along the western flank of the Dallol segment fed by an $2.4 \mathrm{~km}$ deep active magma reservoir buried by evaporitic deposits beneath Dallol (Carniel et al., 2010; Nobile et al., 2012).
The Danakil Depression exhibits both oblique and orthogonal extensional tectonics, and fracture trace analysis has been deemed mandatory to outline the current condition of the axial rifts. In order to evaluate the Quaternary kinematics and geometry of the Dallol Depression, rift axis fracture data have been collected from the fissural basalts of the area. Structural data presented herein were acquired during field campaigns and combined with data from geological mapping and processed Landsat-8 ETM+ images, as the area is difficult to access (Fig. 5). The area includes various structures, such as extensional fractures, elliptical caldera collapses of various sizes, cinder cones, and in some places normal faults with throws not exceeding $10 \mathrm{~m}$. For understanding the kinematics of the Dallol Depression, only the young extensional fractures were analyzed using stereo plots (see Acocella and Korme, 2002).

A total of $\sim 50$ fracture orientations, from both the field survey and Landsat image, and 10 asperities were measured from the fissural and shield basalts of the Gada'Ale volcano (Fig. 5). All measured open fractures have an opening between 0.05 and $1 \mathrm{~m}$ and a length between 3 and $100 \mathrm{~m}$; their 


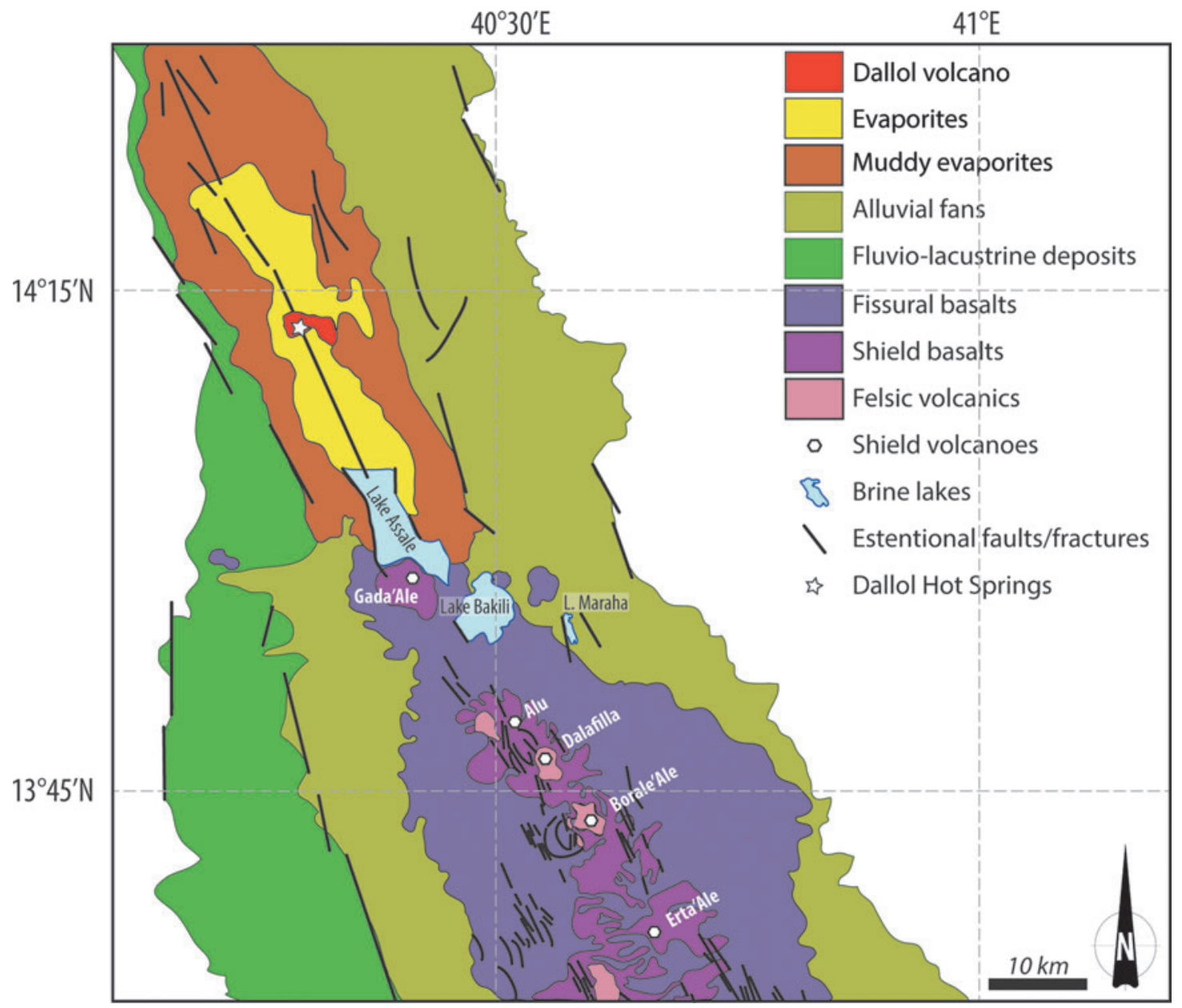

FIG. 4. Simplified geological and structural map of the north-central part of the Danakil Depression, which includes the Dallol volcano and its hydrothermal system (star), the Assale salt plain (evaporites) and the Erta' Ale Range (volcanics). Lithological and structural contacts were obtained from Landsat ETM +2002 bands 7, 5, and 2 and confirmed by field mapping.

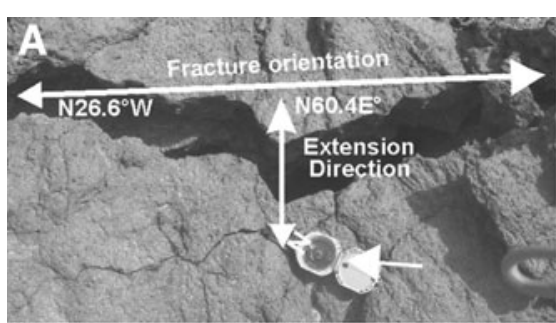

D

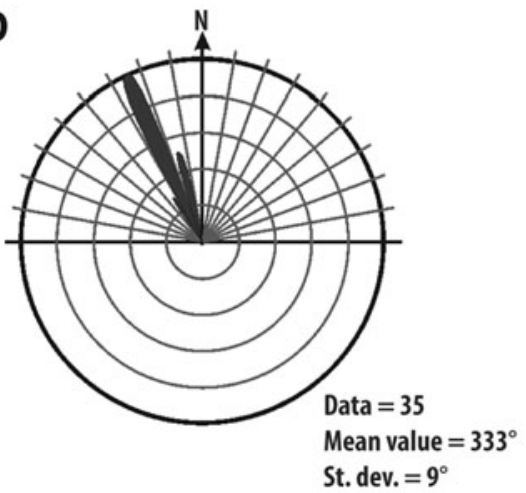

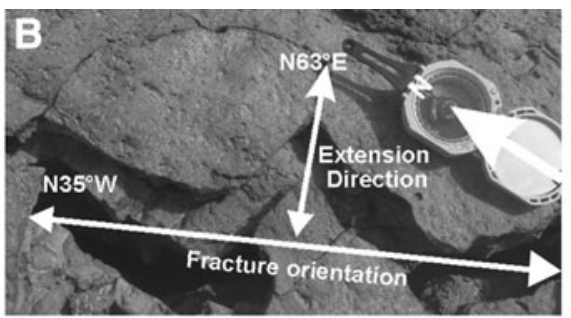

$\mathbf{E}$

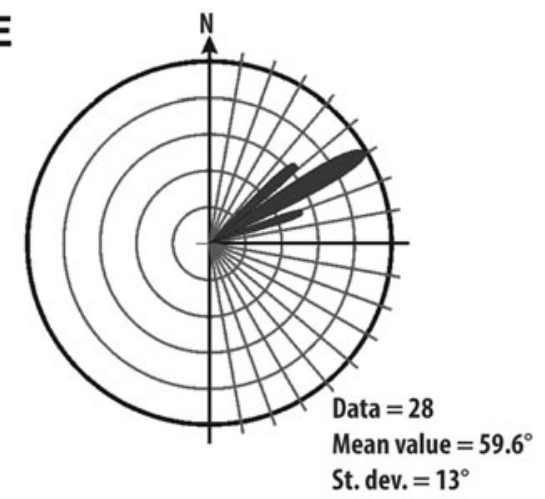

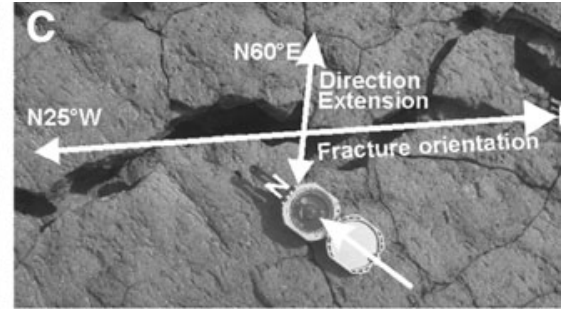

$\mathbf{F}$

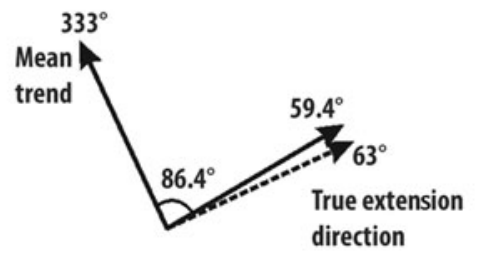

FIG. 5. Representative photographs of extensional fractures $(\mathbf{A}-\mathbf{C})$ and their average orientation $(\mathbf{D})$ and mean opening direction (E) within the Dallol geothermal area, northern Danakil Depression. (F) The $86.4^{\circ}$ angle between the fracture trend and extension direction suggests a nearly orthogonal extension. The compass is $7 \mathrm{~cm}$ in diameter. 
depth of penetration, $\sim 700 \mathrm{~m}$, is inferred from mechanical considerations (Acocella and Korme, 2002). The features representing the convergence of the two fractures are surfaces represented by asperities, which were sharp, fresh, and unaffected by surface processes and other secondary deformation, examples of which are shown. This characteristic, together with the Quaternary age of the rocks, confirms that the extensional fractures were active features in the northern part of the Danakil Depression. Approximately 10 such open fractures, which have clear asperities, were measured and all found to be consistent with an overall ENE-WSW $\left(59.4^{\circ}\right)$ extension direction of the open fractures orthogonal to the mean trend of the axial structures (i.e., $333^{\circ}$ ) (Fig. 5).

\section{The Danakil Depression and the Dallol Geothermal Area}

The Danakil Depression is a narrow, arid lowland plain ( $\sim 250 \mathrm{~km}$ long) mostly lying $\sim 100 \mathrm{~m}$ below sea level (b.s.1.) but reaching as much as $124 \mathrm{~m}$ b.s.l. in Lake Assale (also spelled Lake Asale or Asshale and less frequently known by its official name Lake Karum), Lake Bakili, and near the Dallol volcano (Fig. 4), and therefore represents one of the lowest land areas in Africa and in the world (Table 1) including one of the lowest-elevation subaerial volcano-hydrothermal systems on Earth. It runs inland, approximately NNW to SSE, quasi-parallel to the coast of the Red Sea (funneling out to the south: $\sim 15 \mathrm{~km}$ wide at the north and widening up to $70 \mathrm{~km}$ to the south) from which it is separated by tectonic barriers. The Danakil Depression can be divided in two physiographic domains represented to the north by the Dallol area and to the south by the Erta'Ale volcanic range (Fig. 4). Axial shield volcanoes rising from 0.3 to $1 \mathrm{~km}$ typify the southern part of the Danakil Depression, whereas its northern part is dominated by a largely deserted, $4000 \mathrm{~km}^{2}$ salt plain known as the Dallol or Assale plain, hosting the Dallol volcano.

The western border of the Danakil Depression is bounded by the Ethiopian Escarpment or Highland (the highest peaks standing well above $3500 \mathrm{~m}$ above sea level [a.s.1.]), which includes prominent marginal grabens, such as the Maglala-
Renda and Dergaha-Sheket grabens, the fill deposits of which accommodate a drop in elevation of up to $\sim 3000 \mathrm{~m}$ to the ridgeline of the escarpment and less than $\sim 1000 \mathrm{~m}$ to the marginal areas up to $100-150 \mathrm{~m}$ b.s.l. at the floor of the Danakil Depression. The western border has a more distinct rift architecture and morphology than the eastern border, which comprises the Danakil Alps (average height of $400 \mathrm{~m}$ a.s.l.; highest peak at the Nabro stratovolcano, $2218 \mathrm{~m}$ a.s.l.), a narrow ( $\sim 500 \mathrm{~km}$ long) NW-SE trending volcanic ridge (e.g., Tesfaye et al., 2003; Beyene and Abdelsalam, 2005). To the north, the low volcano-tectonic barriers (including the Jalua and Alid stratovolcanoes, 713 and $904 \mathrm{~m}$ a.s.1., respectively) south of the Gulf of Zula and the city of Mersa Fatma protect the Danakil and Afar Depression from marine flooding; and to the south, the Danakil Depression hosts the $\sim 100 \mathrm{~km}$ long, axial volcanic Erta'Ale Range (NNW-SSE trending), where the Ale Bagu stratovolcano rises up to $1031 \mathrm{~m}$ a.s.l. and Erta'Ale ("smoking mountain" in the Afar language) features a spectacular permanent lava lake (e.g., Barberi and Varet, 1971).

The age of the Dallol dome is postdated by the age of the thick evaporite deposit of the Assale salt plain (see Section 3.1), whereas the hydrothermalism of the area (Dallol Hot Springs, Black Pool and Gaet'ale Lake) was possibly generated by a phreatic explosion in 1926 (e.g., Holwerda and Hutchinson, 1968; Siebert et al., 2010); since then, explosive volcanic episodes, perpetual and ephemeral hydrothermal venting, small geysers and pools, and several seismic events have been reported in the area (e.g., Ogubazghi et al., 2004; Chernet, 2011; Craig et al., 2011; Nobile et al., 2012; personal communication with Afar guides).

The ellipsoidal Dallol dome (ENE-WSW long axis) features an approximately $1 \mathrm{~km}$ main crater atop a wide dome of approximately $5 \mathrm{~km} \mathrm{E-W}$ diameter, located $c a .80 \mathrm{~km}$ NNW from the axially aligned active volcanoes of the Erta'Ale Range. It consists of bedded anhydrite and halite with an elevation of about $45-50 \mathrm{~m}$ above the Assale salt plain (here $124 \mathrm{~m}$ b.s.1.) (Fig. 6). Hydrothermal activity is fueled by water heated and enriched in gases by a shallow magma reservoir that lies primarily beneath the volcano (e.g., Schofield et al., 2014). Field observations permit the recognition of at least three main sites within the Dallol

Table 1. List of the Lowest Point on Land Elevation (B.S.L.) of Geological Depression (COMPIled From Many Sources and Updated from Google Earth)

\begin{tabular}{|c|c|c|c|}
\hline Location & Country & Elevation b.s.l. & Latitude/Longitude $^{\mathrm{a}}$ \\
\hline Dead Sea Depression & Israel, Jordan & $\sim 415 \mathrm{~m}$ & $\begin{array}{l}32^{\circ} 32^{\prime} 15^{\prime \prime} \mathrm{N} \\
35^{\circ} 30^{\prime} 20^{\prime \prime} \mathrm{E}\end{array}$ \\
\hline Sea of Galilee (or Tiberis Lake) & Israel & $\sim 216 \mathrm{~m}$ & $\begin{array}{l}32^{\circ} 48^{\prime} 50^{\prime \prime} \mathrm{N} \\
35^{\circ} 36^{\prime} 22^{\prime \prime} \mathrm{E}\end{array}$ \\
\hline Afar Depression (Assal Lake) & Djibouti & $\sim 157 \mathrm{~m}$ & $\begin{array}{l}11^{\circ} 39^{\prime} 10^{\prime \prime} \mathrm{N} \\
42^{\circ} 25^{\prime} 40^{\prime \prime} \mathrm{E}\end{array}$ \\
\hline Turpan Depression (dry Ayding Lake) & China & $\sim 154 \mathrm{~m}$ & $\begin{array}{l}42^{\circ} 39^{\prime} 27^{\prime \prime} \mathrm{N} \\
89^{\circ} 16^{\prime} 14^{\prime \prime} \mathrm{E}\end{array}$ \\
\hline Qattara Depression (Lybian Desert) & Egypt & $\sim 133 \mathrm{~m}$ & $\begin{array}{l}29^{\circ} 23^{\prime} 39^{\prime \prime} \mathrm{N} \\
26^{\circ} 44^{\prime} 10^{\prime \prime} \mathrm{E}\end{array}$ \\
\hline Karagiye Depression (Vpadina Kaundy) & Kazakhstan & $\sim 133 \mathrm{~m}$ & $\begin{array}{l}43^{\circ} 27^{\prime} 25^{\prime \prime} \mathrm{N} \\
51^{\circ} 46^{\prime} 10^{\prime \prime} \mathrm{E}\end{array}$ \\
\hline $\begin{array}{l}\text { Danakil Depression (near the Dallol volcano; } \\
\text { Lake Karum; Lake Bakili) }\end{array}$ & Ethiopia & $\sim 124 \mathrm{~m}$ & $\begin{array}{l}14^{\circ} 15^{\prime} 30^{\prime \prime} \mathrm{N} \\
40^{\circ} 18^{\prime} 00^{\prime \prime} \mathrm{E}\end{array}$ \\
\hline
\end{tabular}

\footnotetext{
${ }^{\mathrm{a} A p p r o x i m a t e .}$
} 

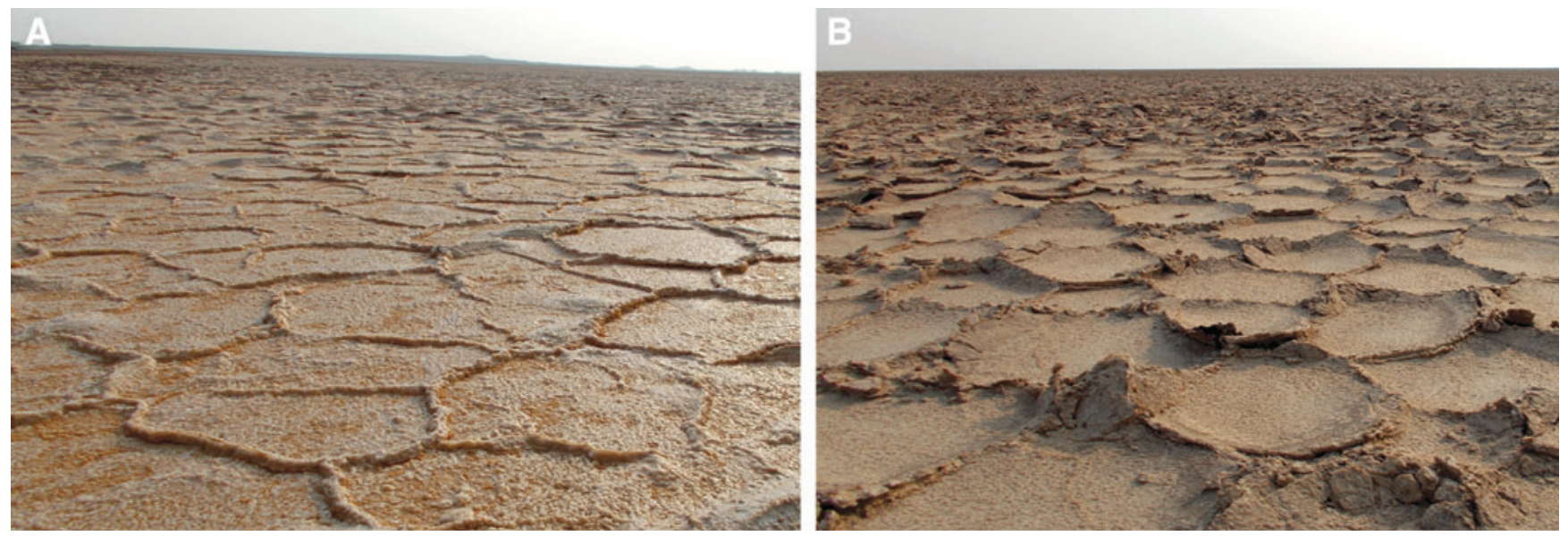

FIG. 6. Panoramic views of the Assale salt plain (see also Fig. 4). Photographs show the regular polygonal patterns (A) and their breakage forming tepee desiccation features (B) on the (halite) salt plain. The average diameter of an individual desiccation cell is approximately $60 \mathrm{~cm}$, but polygons can easily reach $3 \mathrm{~m}$ diameter with $20-40 \mathrm{~cm}$ high tepee rims.

hydrothermal system, each with distinct vent characteristics: the Dallol Hot Springs, the Gaet'ale Lake, and the Black Pool (Fig. 7)

The Dallol Hot Springs is a hydrothermal field less than $1 \mathrm{~km}^{2}$ in diameter featuring disseminated ephemeral and inactive fumaroles and geyser cones steaming and spitting hot and warm brines, forming mounds and yellow-green pools that are mostly concentrated in the Dallol volcanic crater (Fig. 7). It is likely that seasonal variations, magmatic and seismic events, and anthropogenic intervention are among the many factors affecting the equilibrium of the hydrothermal system. Since 2013, it has been possible to document newly forming crevices, fumaroles, small vents, and steaming pools (with a SSE trend distribution) along the south flank of the crater and at its base on the nearby salt plain. The Dallol dome still hosts the rusting ghost of the mining camp $\left(14^{\circ} 14^{\prime} 16.19^{\prime \prime} \mathrm{N}, 40^{\circ} 17^{\prime} 44.93^{\prime \prime} \mathrm{E}\right)$ of the Ralph M. Parsons Company, USA, which conducted exploration in this area from 1958 to 1968 .

Gaet'ale Lake $\left(14^{\circ} 12^{\prime} 48.50^{\prime \prime} \mathrm{N}, 40^{\circ} 19^{\prime} 16.50^{\prime \prime} \mathrm{E}\right)$ (Master, 2016), also called by the Afars Geda Lé (which means "spring water" in the Afar language) and also informally known as the Yellow, Boiling, Geyser, Killer, and Acidic Lake (Warren, 2016, and other informal sources), is a hydrothermal pool located less than $4 \mathrm{~km}$ SE of the Dallol volcanic crater. The perpetually bubbling waters of Gaet'ale
FIG. 7. Satellite overview of the Dallol area and its hydrothermal sites. The hydrothermalism related to the Dallol volcanism includes (1) the active and inactive Dallol Hot Springs mostly concentrated in the Dallol crater, (2) the active and inactive Gaet'ale Pool and related satellite pools and pits that can be observed along the (NW-SE) facture alignment (dashed line), and (3) the "bischofite" field including the Black Pool in the area of the so-called Black Mountain. DK-10-04B: drill hole, Allana Potash Corporation (2012). Source data: Landsat 8 pan-sharpened RGB-321 color composite acquired on October 6, 2016. Image courtesy of the U.S. Geological Survey (scene ID: LC81680502016280LGN01).

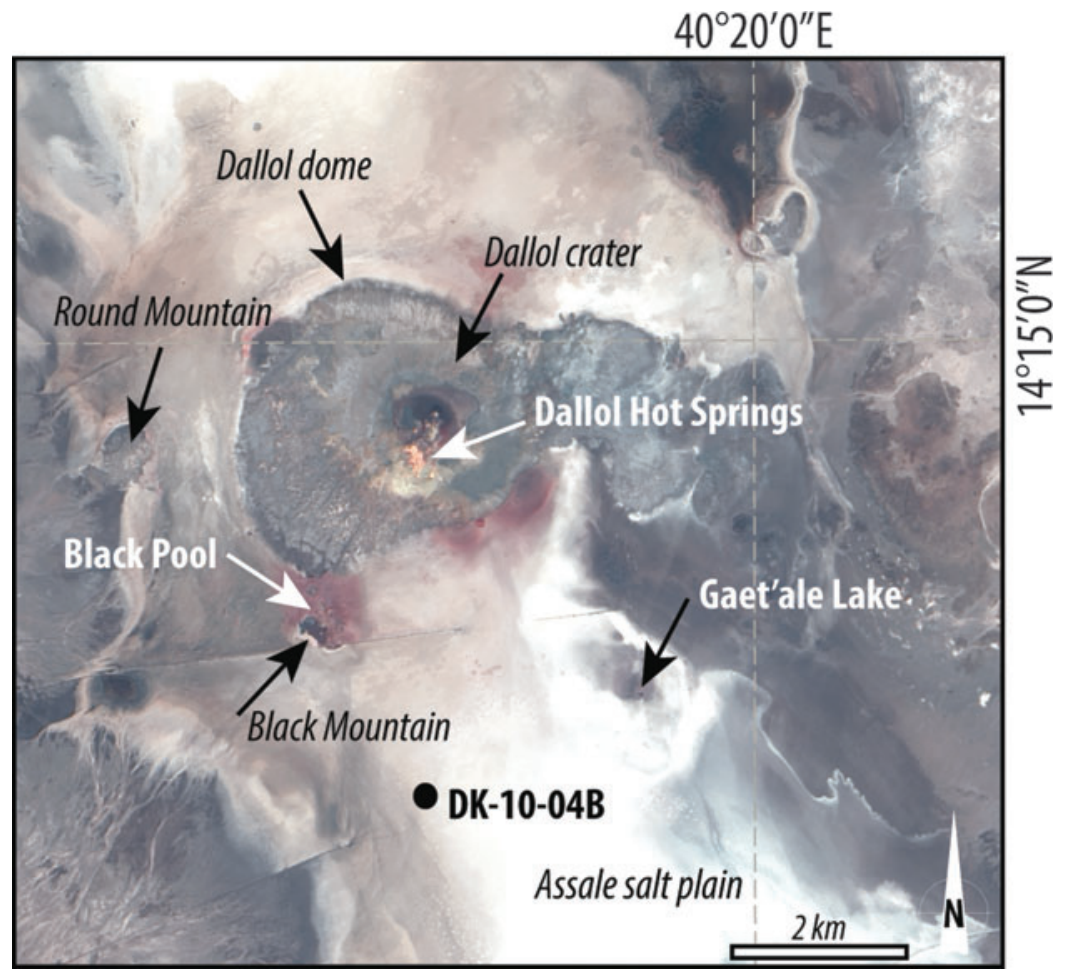


Lake have average $\mathrm{pH}$ and temperature values of 3 and $55^{\circ} \mathrm{C}$, respectively. Gaet'ale Lake is the largest (less than $50 \mathrm{~m}$ in diameter) of a number of small active and relict pools aligned along a NW-SE tectonic trend running parallel to the shallow dike intrusion feeding the geothermal activity of the Dallol volcano on its western flank (Nobile et al., 2012). According to Master (2016), the Gaet'ale water spring formed after the 2004-2005 seismic events as a small $3 \mathrm{~m}$ high geyser that became in the following 5 years a muddy-briny pool of water. Since the first survey of Gaet'ale Lake in 2013, new small pits (from less than a meter up to a few meters) have opened along the NW-SE tectonic lineament intersecting the southeast of the Dallol crater, some of them enlarged due to dissolution effects while others are presently ephemeral and relict forms (Fig. 7).

The Black Pool is a small, hydrous magnesium chloriderich pool of slightly boiling acid $\left(14^{\circ} 13^{\prime} 12^{\prime \prime} \mathrm{N}, 50^{\circ} 17^{\prime} 15^{\prime \prime} \mathrm{E}\right.$; $122 \mathrm{~m}$ b.s.l.; $T_{\text {average }} 56^{\circ} \mathrm{C}$ and $\mathrm{pH} 1.4$ were recorded in January 2018) located less than $2.5 \mathrm{~km} \mathrm{SW}$ of the Dallol crater, on the north side of the $c a .2 \mathrm{~m}$ high dark mound informally named Black Mountain and associated with potash ore deposits and surrounded by a large bishofite deposit and an active fumarole field (Holwerda and Hutchinson, 1968; Warren, 2016; field observation). Bishofite outflow events were reported in 2011-2012, and the size of this geothermal area was estimated at $0.3 \mathrm{~km}^{3}$ in 2015 (Franzson et al., 2015).

Until only several years ago, the Dallol area was considered one of the most remote places on Earth. Only at the end of 2015 did dirt and gravel roads from Hamed'Ela (also reported as Ahmed'Ela, Ahmed'lla, Amed Hela, or Ahmedela) reach the now-permanent Afar village, from where it is possible to access the Danakil salt plain, the Dallol hydrothermal area, and the nearby Canadian Allana Potash Corporation mining camp_engaged in the development of potash assets in Ethiopia (Allana Potash Corporation, 2012)-to Berhale (about $75 \mathrm{~km}$ away) and to Mekelle (about $200 \mathrm{~km}$ to the SW), the largest city in northern Ethiopia. Recent developments in the region have rapidly changed, and will continue to improve, the lives of the nomadic Afars and miners. Here, Afars are still mining salt rocks and transporting the production from the Danakil salt plain to Berhale by camel and donkey caravans (Fig. 1B).

\subsection{Dallol geothermal area: stratigraphic and minero-petrographic features}

Stratigraphic data for the northern Danakil area are scarce in the lietrature, and the definition of the main stratigraphic units is mostly unclear. At very local scales, however, a different stratigraphic nomenclature and subdivisions for the formations and rock units have been proposed (Table 2; Fig. 8) (for reviews see Ralph M. Parsons Company, 1966; Holwerda and Hutchinson, 1968; Bannert et al., 1970; Brinkmann and Kürsten, 1970; Hutchinson and Engels, 1970; Lalou et al., 1970; Bonatti et al., 1971; Garland, 1980; PEC Engineering Division Mine, 1984, 1986; Smewing and McKeon, 1989; Carniel et al., 2010; Allana Potash Corporation, 2011, 2012; Abbate et al., 2015; Warren, 2016; Varet, 2018).

Based on the stratigraphic units already recognized in the literature (Table 2; Fig. 8), we propose for the Dallol area a stratigraphic reconstruction based on our field observation (see also Fig. 4). Nonetheless, more field observations and detailed studies are required in order to obtain a well-defined stratigraphy for the northern Danakil Depression.

The northern part of the Danakil Depression-the location of the Dallol area-is a conical, tectonic depositional basin that opened southward from the Gulf of Zula to the central Afar region as part of the subaerial segment of the crustal spreading rift process that began in the early Miocene Epoch (Figs. 1-4). The rifted Precambrian granitic and metamorphic basement complex does not outcrop within the northern Danakil Depression but is exposed in the Ethiopian

Table 2. Schematic Stratigraphy Reconstruction of the Danakil Depression and Dallol Geothermal Area Compiled from Different Sources (See References in the TeXt)

\begin{tabular}{|c|c|c|c|}
\hline Age & Formation/Units & Description & Volcanics \\
\hline \multirow[t]{3}{*}{ Pliocene-Holocene } & Assale salt plain & $\begin{array}{l}\text { Halite, gypsum, potash salts, clays, and } \\
\text { shale deposits }\end{array}$ & \multirow{3}{*}{$\begin{array}{l}\text { Intercalated with the } \\
\text { Aden Volcanics } \\
\text { units }\end{array}$} \\
\hline & Afdera Formation & $\begin{array}{l}\text { Lacustrine and fluvial sediments (marls, } \\
\text { gravels, limestone, and diatomites). In } \\
\text { the Dallol area the Afdera Formation } \\
\text { is almost missing, and the Enkafala } \\
\text { Formation transitionally passes to the } \\
\text { Assale salt plain. }\end{array}$ & \\
\hline & $\begin{array}{l}\text { Enkafala Formation }{ }^{\text {a }} \text { (also } \\
\text { reported as White Series } \\
\text { and partially overlapping } \\
\text { with the Zariga Formation) }\end{array}$ & $\begin{array}{l}\text { Gypsiferous deposits, bedded halite, } \\
\text { anhydrite, potash salts indicating } \\
\text { a marine transgression }\end{array}$ & \\
\hline Miocene & $\begin{array}{l}\text { Danakil Formation }^{\text {a }} \text { (also } \\
\text { reported as Red Series } \\
\text { and equivalent of the } \\
\text { Dogali Formation) }\end{array}$ & $\begin{array}{l}\text { Conglomerates and sands with } \\
\text { locally gypsiferous madstones and } \\
\text { limestones intercalated with basalt } \\
\text { flows intrusion unconformably } \\
\text { overlain by the Enkafala Formation }\end{array}$ & $\begin{array}{l}\text { Intercalated with } \\
\text { basalt lava flows } \\
\text { and intrusions, and } \\
\text { ashes of the Afar } \\
\text { Basalts }\end{array}$ \\
\hline
\end{tabular}

\footnotetext{
${ }^{\text {a }}$ The Evaporite Sequence (Holwerda and Hutchinson, 1968) described for the northern portion of the Danakil Depression-specifically about $10 \mathrm{~km}$ west of Dallol volcano, in the so-called Musley area-may partially correspond to the marine sediments of the top part of Danakil Formation and to the Enkafala Formation (see also Fig. 8).
} 


\section{Stratigraphic column \\ DK-10-04B DRILL CORE} column of the Allana DK-10-04B drill hole $(-124.33 \mathrm{~m}$ of elevation b.s.1.), which is located less than $4 \mathrm{~km}$ south of the Dallol volcano (see Fig. 7). Here the Evaporite Sequence (Holwerda and Hutchinson, 1968; Warren, 2016) is represented from bottom to top by the (1) Lower Salt Rock Formation consisting of halite with coarse anhydrite and clay layers, the (2) Houston Formation consisting of anhydrite with clay layers rich in potash mineralskainite, halite, carnallite, sylviteand the (3) Upper Rock Salt Formation consisting of halite with gypsum and anhydrite interbedded with clays. The detrital deposits (alluvial gravels, sandstones, detrital gypsum, and halite) of the Evaporite Sequence are not present in this area. The Houston Formation (from bottom to top) contains the most interesting potash-bearing intervals: Kainite, Intermediate and Sylvite Members, and the Marker Beds. Modified from Allana Potash Corporation (2012).
FIG. 8. Simplified stratigraphic

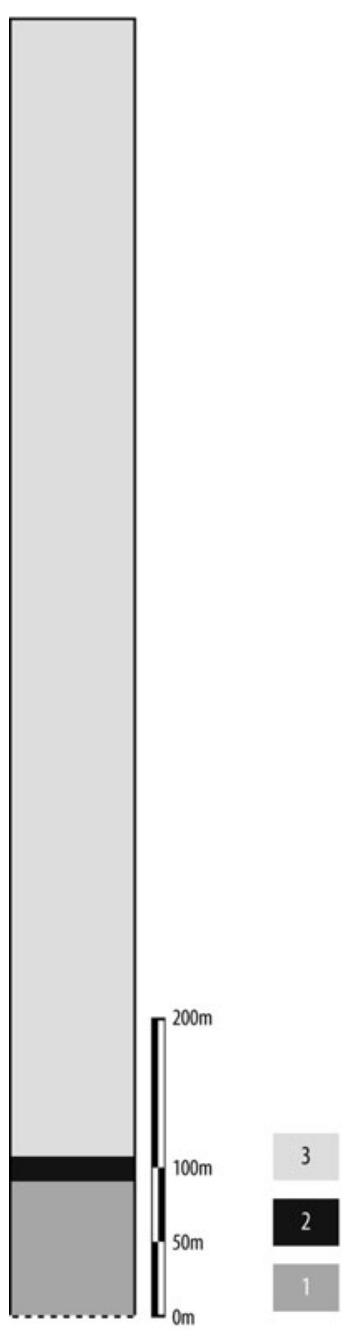

highlands adjacent to the Danakil Depression and in the Danakil Alps.

The northern Danakil Depression is dominated at the surface by wide evaporite deposits (Assale salt plain) above which, to the south, NNW-SSE (rift axis) QuaternaryRecent volcanic edifices (basalts) gently rise from 0.3 to $1 \mathrm{~km}$ (Fig. 4). The evaporitic deposits interfingering continental (fluvial and lacustrine sediments) and shallow marine deposits are set on multiple events of fissure-fed basaltic lava flows. At the base of the steep escarpments, flat layers of sand-to-silt-sized alluvial deposits overlain by alluvial fan deposits are observed on the depression floor.

The massive, marine evaporite deposits (along the axis) of the Danakil Depression formed when the region was connected at the north to the Red Sea (about 200,000 years ago), which remained isolated during the Pleistocene (Holwerda and Hutchinson, 1968; Tazieff et al., 1969; see Varet, 2018, for review). Periodic freshwater flooding from the surrounding highlands has been and still is responsible for the formation of recent salt deposits (Assale salt plain). Danakil evaporite deposits have been targeted by several exploration programs since the early 1900 s when the pre- liminary survey was conducted by Italian explorers Adriano and Tullio Pastori and the CMC (Compagnia Mineraria Coloniale), an Italian mining company that first discovered the potash (K-rich minerals) ore deposit in the Dallol area and revealed its potential (for a review of Danakil potash exploration, see Lupi, 2009). According to the (public) data collection from the drill core $(\mathrm{ca} .1000 \mathrm{~m}$ drill cores) and geophysical field surveys presently available from all the potash exploration programs, the deepest part of the Danakil Depression is filled with at least $2 \mathrm{~km}$ thick sediments that comprise the Danakil, Enkafala, and Afdera Formations (Mitchell et al., 1992; Redfield et al., 2003; Allana Potash Corporation, 2011; Darrah et al., 2013; Warren, 2016).

The shallow magma intrusions buried by the evaporitic deposits at the Dallol area (Nobile et al., 2012) control the dome-shaped uplifted deposits that in turn result in strongly altered and now partially eroded halite and potash beds. Moreover, magma intrusions are the engine of the Dallol geothermal field (Holwerda and Hutchinson, 1968; Nobile et al., 2012; Darrah et al., 2013). In the Dallol volcanic area beneath the crust of modern salt (halite) dissolved and re-precipitated by episodic floods from Assale Lake (e.g., Martini, 1969), the stratigraphic sequence consists of interbeds of evaporite mineral phases including halite, gypsum, anhydrite, kieserite, and shale with a potash succession including mostly carnallite, kainite, and bischofite at places showing fluid and gas inclusion (such as $\mathrm{CH}_{4}, \mathrm{H}_{2} \mathrm{O}, \mathrm{CO}_{2}$, $\mathrm{H}_{2} \mathrm{O}_{\text {vap}}$ ) (Table 3). A marine brine source of the kainitite and carnallite units at more than $800 \mathrm{~m}$ depth in the salt flat in the Dallol volcano area could explain the high levels of $\mathrm{Mg}$ and $\mathrm{SO}_{4}$ (Holwerda and Hutchinson, 1968; Warren, 2016).

\subsection{Dallol geothermal area: the hot springs}

Many typical terrestrial hydrothermal features characterize the Dallol hot springs: hot acidic waters, active and inactive fields of single- to multi-vented spring mounds or cones, small geysers, fumaroles, circular to subcircular shallow ponds and/or pools forming characteristic terraced surfaces filled by hot brines, together with salts and sulfur/ sulfide deposits emanating intense $\mathrm{S}$ - and $\mathrm{Cl}$-rich vapors and (recrystallized) iron-oxide crusts mixed with fine, older clay sediments in the form of muddy evaporites. In the following, we outline the major characteristics and morphological features of the Dallol geothermal area.

3.2.1. Water geochemistry. Thermal waters emerging from the Dallol area consist of hot (up to $c a .112^{\circ} \mathrm{C} \pm 0.1^{\circ} \mathrm{C}$; in situ temperature measurement performed using a portable VWR digital thermometer with a precision of $\pm 0.1^{\circ} \mathrm{C}$ ), hyperacidic, $\mathrm{Na}-\mathrm{Cl}$ brines with exceptional chemical-physical characteristics entirely lacking in carbonate species and with high chloride content, which can be summarized as follows: (i) the lowest measured $\mathrm{pH}$ value is $0(\mathrm{pH}$ measurement performed using a multiparameter WTW Model 340i with an accuracy of \pm 0.1 coupled with test strips capable of determining $\mathrm{pH}$ ranges with as high an accuracy as possible, as an instrument of control); (ii) high TDS (total dissolved salts) content up to $366 \mathrm{~g} / \mathrm{L}$; and (iii) extremely high concentrations of $\mathrm{Fe}$ and $\mathrm{Al}$ have been recorded up to 22,000 and $1,100 \mathrm{ppm}$, respectively (Table 4). As suggested by 
Table 3. List of Different Mineral Phases at the Dallol Area Compiled from Field AND LABORATORY OBSERVATIONS (ITALICS) AND FROM LiTERATURE (HUTCHINSON AND ENGELS, 1970; Allana Potash Corporation, 2011, 2012; WARREN, 2016, AND REFERENCES THEREIN)

\begin{tabular}{|c|c|}
\hline Mineral type & Formula \\
\hline \multicolumn{2}{|l|}{ Native elements } \\
\hline Sulfur & $S$ \\
\hline Iron & $\mathrm{Fe}$ \\
\hline \multicolumn{2}{|c|}{ Sulfates, hydrated sulfates } \\
\hline Gypsum & $\mathrm{CaSO}_{4} \cdot 2 \mathrm{H}_{2} \mathrm{O}$ \\
\hline Anhydrite & $\mathrm{CaSO}_{4}$ \\
\hline Kieserite & $\mathrm{MgSO}_{4} \cdot \mathrm{H}_{2} \mathrm{O}$ \\
\hline Epsomite & $\mathrm{MgSO}_{4} \cdot 7 \mathrm{H}_{2} \mathrm{O}$ \\
\hline Arcanite & $\mathrm{K}_{2} \mathrm{SO}_{4}$ \\
\hline Thenardite & $\mathrm{Na}_{2} \mathrm{SO}_{4}$ \\
\hline Polyhalite & $\mathrm{K}_{2} \mathrm{Ca}_{2} \mathrm{Mg}\left(\mathrm{SO}_{4}\right)_{4} \cdot 2\left(\mathrm{H}_{2} \mathrm{O}\right)$ \\
\hline Kainite & $\mathrm{KMg}\left(\mathrm{SO}_{4}\right) \mathrm{Cl} \cdot 3 \mathrm{H}_{2} \mathrm{O}$ \\
\hline Leonite & $\mathrm{K}_{2} \mathrm{Mg}\left(\mathrm{SO}_{4}\right)_{2} \cdot 4\left(\mathrm{H}_{2} \mathrm{O}\right)$ \\
\hline Jarosite & $\mathrm{KFe}_{3}^{3+}\left(\mathrm{SO}_{4}\right)_{2}(\mathrm{OH})_{6}$ \\
\hline \multicolumn{2}{|l|}{ Halides } \\
\hline Halite & $\mathrm{NaCl}$ \\
\hline Bischofite & $\mathrm{MgCl}_{2} \cdot 6 \mathrm{H}_{2} \mathrm{O}$ \\
\hline Sylvite $\mathrm{a}^{\mathrm{a}}$ & $\mathrm{KCl}$ \\
\hline Carnallite $^{\mathrm{a}}$ & $\mathrm{KMgCl}_{3} \cdot 6 \mathrm{H}_{2} \mathrm{O}$ \\
\hline Rinneite & $\mathrm{K}_{3} \mathrm{NaFe}^{2+} \mathrm{Cl}_{6}$ \\
\hline \multicolumn{2}{|l|}{ Iron oxides } \\
\hline Hematite & $\mathrm{Fe}_{2} \mathrm{O}_{3}$ \\
\hline Magnetite & $\mathrm{Fe}^{2+} \mathrm{Fe}_{2}^{3+} \mathrm{O}_{4}$ \\
\hline \multicolumn{2}{|c|}{ Fluid/gas inclusions ${ }^{b}$} \\
\hline Methane & $\mathrm{CH}_{4}$ \\
\hline Water & $\mathrm{H}_{2} \mathrm{O}$ \\
\hline Carbon dioxide & $\mathrm{CO}_{2}$ \\
\hline Water vapor & $\mathrm{H}_{2} \mathrm{O}_{\text {vap }}$ \\
\hline
\end{tabular}

${ }^{\text {a}}$ Potash minerals.

${ }^{\mathrm{b}}$ Chlorine minerals commonly contain liquid, gas, or solid inclusions composed of $\mathrm{CO}_{2}$ and hydrocarbons.

Note: no sulfides were detected.

classification diagrams such as the square classification diagram of Langelier and Ludwig (1942), these unique thermal waters plot close to typical present-day Mediterranean seawater composition but with a salinity 10 times higher (Fig. 9). Although the salinity is very similar to that of esti- mates of the Dead Sea in 2002, the relationships between the fundamental ions are very different (Capaccioni et al., 2003). For example, contents of $\mathrm{Na}^{+}$appear slightly lower with respect to those expected from a conservative evaporation of marine $\mathrm{Cl}^{-}$, probably due to the precipitation of $\mathrm{NaCl}$ (Fig. 9B). $\mathrm{Mg}^{2+}$ is also generally lower, whereas $\mathrm{SO}_{4}{ }^{2-}$ concentration is apparently less influenced by anhydrite precipitation than in the Dead Sea basin. $\mathrm{K}^{+}$appears 3-4 times more concentrated with respect to that expected according to conservative evaporation. Calcium shows similar behavior, although to a lesser degree. Considering $\mathrm{Br}^{-}$as a conservative indicator, instead of $\mathrm{Cl}$, ions such as $\mathrm{Na}^{+}, \mathrm{K}^{+}, \mathrm{Ca}^{2+}$ including $\mathrm{Cl}^{-}$, appear largely to exceed the expected values; $\mathrm{F}^{-}$in particular displays concentrations up to 100 times those expected.

The conceptual model describing the origin of these thermal waters must be based on both that the local elevation is $120 \mathrm{~m}$ b.s.l. and that the waters are hyperacidic and gas-rich. Elevated salinity should result from the leaching of evaporite salts and/or from evaporation of connate/fossil seawater, coupled with the precipitation of soluble salts, such as $\mathrm{NaCl}, \mathrm{CaSO}_{4}$, and $\mathrm{CaF}_{2}$. The extremely low measured $\mathrm{pH}$ values can only be the result of inputs of very acidic gases, such as $\mathrm{HCl}, \mathrm{HF}, \mathrm{SO}_{2}$, and $\mathrm{H}_{2} \mathrm{~S}$ as testified by the observed excesses of anions. The only possible source of these anions is the dissolution of very acidic gaseous species possibly related to processes of magma degassing at depth. The acidity of the water is then maintained due to the lack of alkaline capacity of the host rocks. The excess of cations is likely related to intense leaching of silicate rocks, although this cannot be confirmed due to a lack of data regarding rock composition at depth. The dissolution of basaltic rocks at depth seems to be a negligible phenomenon since acidity should produce a significant increase in $\mathrm{Mg}^{2+}$, which is not observed.

3.2.2. Mounds, geysers, pools, and terraces. The Dallol crater is characterized by localized hydrothermal activity with intermittent small geysers, salt spring mounds, and cones (Fig. 10) emanating extremely acidic ( $\mathrm{pH} \sim 0-0.2$ or below 0; Franzson et al., 2015, reported $\mathrm{pH}$ values of -0.74 [winter 2012] for these acidic waters), hypersaline, hot (up to $112^{\circ} \mathrm{C}$ ) hydrothermal waters that form pools, and terrace and microterrecette morphologies (Fig. 10C).

Table 4. Geochemical Composition of the Geothermal Waters Collected in October 2013

from the Dallol Hot Spring Site (see Fig. 7). Water Source Samples Were Collected FROM SiTES D1 $\left(14^{\circ} 14^{\prime} 16.69^{\prime \prime} \mathrm{N}, 40^{\circ} 17^{\prime} 52.08^{\prime \prime} \mathrm{E}\right)$ AND D2 $\left(14^{\circ} 14^{\prime} 21.07^{\prime \prime} \mathrm{N}, 40^{\circ} 17^{\prime} 56.08^{\prime \prime} \mathrm{E}\right)$ (SEE FIG. 11)

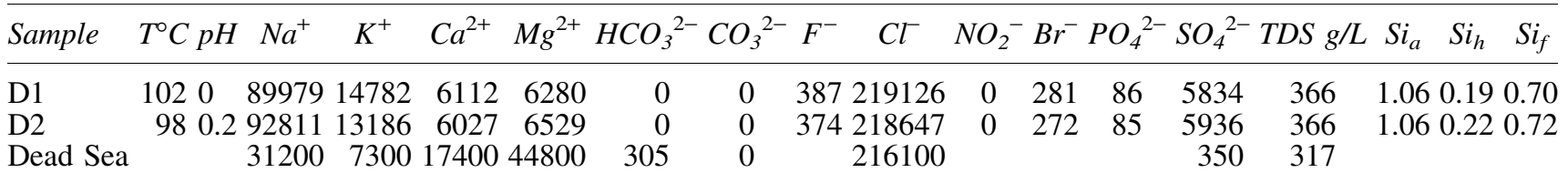

All concentrations are in $\mathrm{mg} / \mathrm{L}$. TDS $=$ total dissolved salts. $\mathrm{Si}_{\mathrm{a}}=\mathrm{Si}_{\text {anidrite }} \cdot \mathrm{Si}_{\mathrm{h}}=\mathrm{Si}_{\text {halite }} \cdot \mathrm{Si}_{\mathrm{f}}=\mathrm{Si}_{\text {fluorite }}$. Data are compared to the hypersaline thermal water of the Dead Sea (B. Capaccioni, unpublished data).

\begin{tabular}{lcccccccccc}
\hline Sample & $\mathrm{Al}$ & $\mathrm{Cd}$ & $\mathrm{Co}$ & $\mathrm{Cr}$ & $\mathrm{Cu}$ & $\mathrm{Fe}$ & $\mathrm{Mn}$ & $\mathrm{Ni}$ & $\mathrm{Ti}$ & $\mathrm{Zn}$ \\
\hline D1 & 1071 & 1.8 & 1.6 & 1.7 & 77.8 & 22130 & 870.9 & 0.7 & 1.5 & 78 \\
D2 & 942.3 & 1.6 & 1.5 & 1.5 & 73.1 & 20930 & 819.4 & 0.6 & 1.4 & 76.2
\end{tabular}

All concentrations are in ppm. 


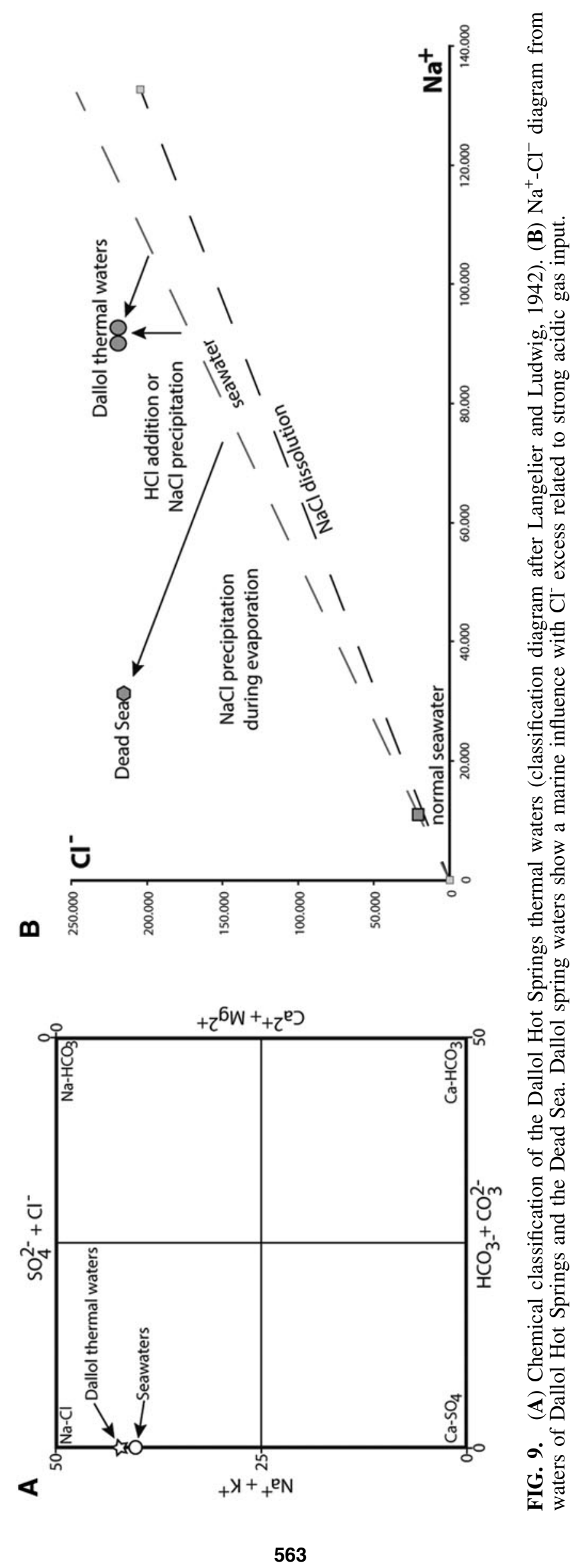


The Dallol Hot Springs' center frequently changes its position (Fig. 11), as evidenced by field monitoring (from 2013 to 2018), including significant water table fluctuation, and confirmed by a field of relict hydrothermal structures such as inactive (relict) mounds, fossil terraces, dried pool, and mushroom-like structures (see below). The fluctuation of the geothermal water level and ephemeral position of the spring sources must be connected to the combination of evaporative and groundwater processes and magmatic activities.
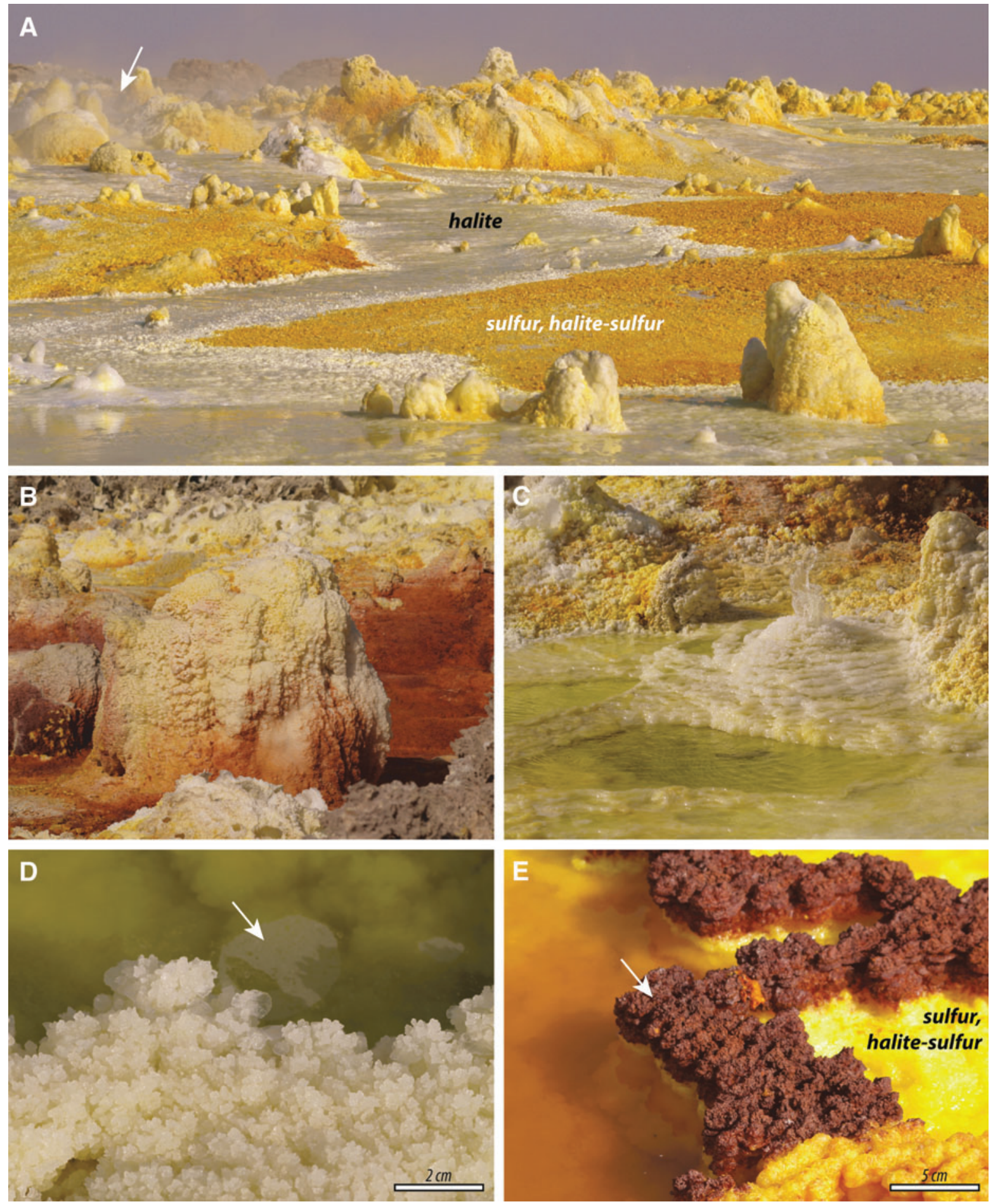

FIG. 10. Dallol Hot Springs site (see Fig. 7). (A) Panoramic view of a field of chimneys, cones, and spring mounds, and sulfur and halite deposits. (B) Circular to subcircular halite mound ( $\sim 1 \mathrm{~m}$ high). Note the red-brownish color on the ground and on the mound walls, reflecting oxidation of Fe in the dry mounds geyser ponds. (C) An erupting halite geyser (arrow, $\sim 40 \mathrm{~cm}$ high). Note that the microterraces originate from the slope of the mound. (D) Halite (white) crystal formation on briny water surface. Note the thin salt veils floating on the water surface (arrow). (E) Sulfur and halite-sulfur deposits. Note the oxidation of Fe when exposed to the air (arrow). 
Salt mounds and cones range in size from several tens of centimeters to $3 \mathrm{~m}$ in height and have near-circular shapes that can reach several meters in diameter at their bases (Figs. 10A-10C, 12). These rarely occur as isolated bodies; mostly they generate a field of mounds or cones reaching about the same height (in the same field).

The Dallol geysers, cones, and hot springs spit water and release steam $\left(\mathrm{H}_{2} \mathrm{O}\right)$ and gas dominated by hydrogen sulfide $\left(\mathrm{H}_{2} \mathrm{~S}\right)$, sulfur dioxide $\left(\mathrm{SO}_{4}\right)$, hydrogen chloride $(\mathrm{HCl})$, and minor carbon dioxide $\left(\mathrm{CO}_{2}\right)$. The waters of the Dallol springs have temperatures exceeding $100^{\circ} \mathrm{C}$ at the vent source (the highest temperature recorded being $112^{\circ} \mathrm{C}$ ),
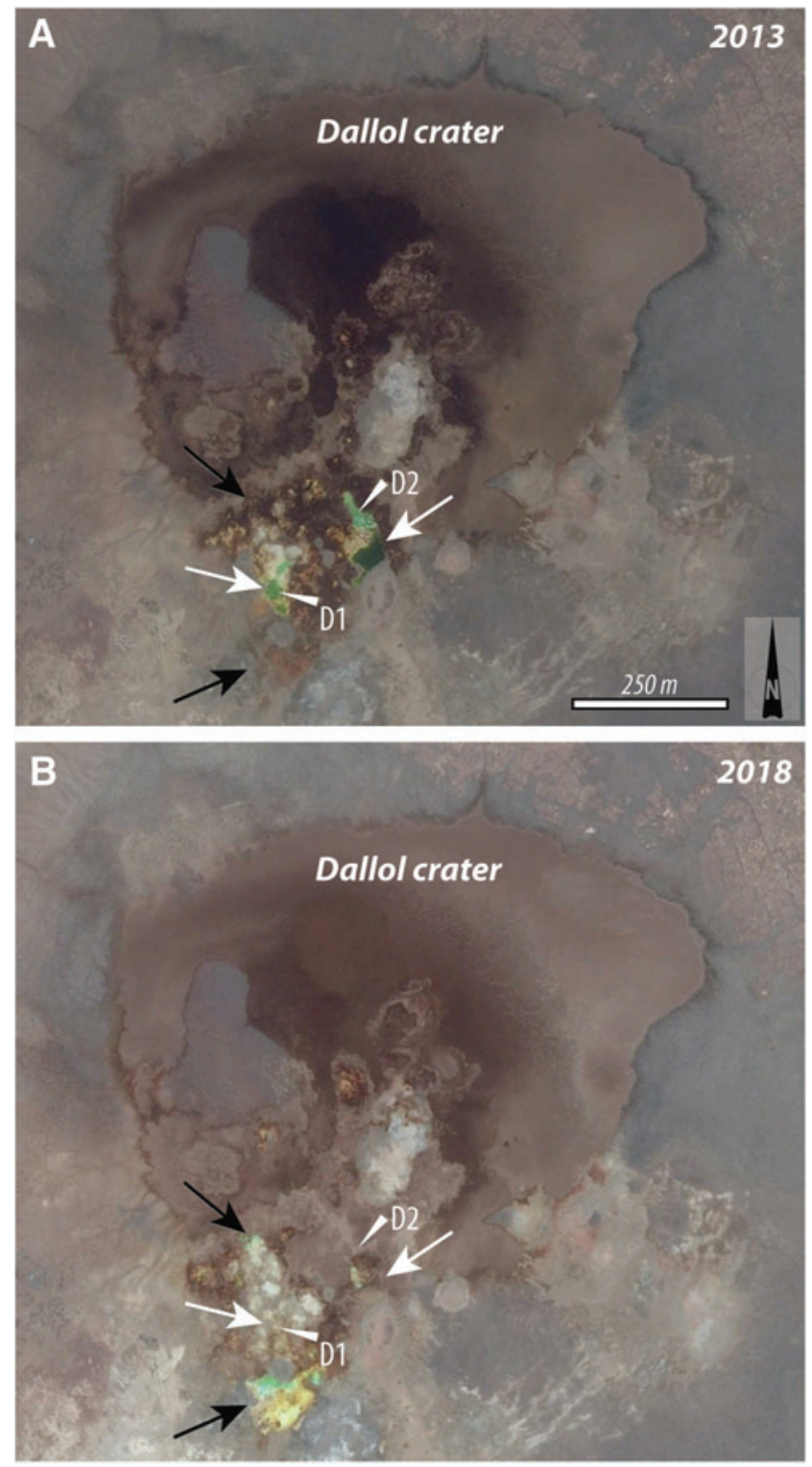

FIG. 11. Satellite view of the Dallol crater showing the location of the ephemeral hydrothermal hot springs (arrows) in 2013 (A) and in 2018 (B). In both panels the hydrothermal systems active in 2013 are indicated with white arrows, whereas black arrows indicate systems active in 2018. Data source: Google Earth (2018 imagery: CNES/Airbus; 2013 imagery: DigitalGlobe, image centered at $14^{\circ} 14^{\prime} 25.25^{\prime \prime} \mathrm{N}$, $\left.40^{\circ} 17^{\prime} 57.78^{\prime \prime} \mathrm{E}\right)$. Note the D1 and D2 are the water sampling sites selected for water geochemistry in 2013 (see also Table 4). forming shallow, semicircular to circular ponds and pools of less than $1 \mathrm{~m}$ to tens of meters in diameter filled with light yellowish or yellow-greenish brines, which are commonly contaminated with mud. The largest pool $\left(\sim 1000 \mathrm{~m}^{2}\right.$ wide $)$ with slightly boiling, dark green-brownish water at the Dallol Hot Spring site was observed in October 2013; In this now dry area, it is now possible to observe the sparse fluid and gas escape apertures (vents) from which the hydrothermal waters were rising.

The supersaturated water, especially at the source vent, engenders rapid deposition of white, yellow, and orange salt precipitates that alter to red-brownish colors reflecting the oxidation of $\mathrm{Fe}$ (e.g., Figs. 10 and 12). The exposed ground of the dried pools shows features of the inactive hydrothermal fields that could be directly compared with the nearby active analogs such as relict mounds and terrace structures (Figs. 13 and 14).

Terrace morphologies at the Dallol volcano resemble those observed in the Mammoth Hot Springs of Yellowstone National Park and other similar settings. Despite their different chemical compositions-at Yellowstone, terraces are carbonate, whereas at Dallol they consist of halite-they produce closely comparable morphologies. Similarly to Yellowstone, the decimeter- to centimeter-scale terraces at Dallol are bounded by steep-sloped rims that function as dividers between pools at different levels (Figs. 10C and 14). Hot water flows from the top of the vent down to the distal sectors of the spring system exhibit a rapid drop of temperature-ranging from $100-112^{\circ} \mathrm{C}$ at the exit from the hot spring down to 33$40^{\circ} \mathrm{C}$ in the distal pools - that could have a significant influence upon the distribution of the microbial communities potentially hosted by the spring system. The largest of these pool structures measure several square meters at their surfaces.

Where the gradients of the spring system are lower, a dense network of salt rims is the likely product of the combined action of reduced gradients and the salt precipitation favored by the rapid reduction of the water temperature. At the surfaces of the pools, where the temperature falls most rapidly, thin saline films can be formed in only a few minutes and are clearly visible from direct field observation. As a result of continuous water flow at the surface of the pools, these newly formed films tend to migrate and accumulate at their edges, such that they thicken the salt rims and favor the formation of small-scale terrace structures. Salt precipitation probably also induces some rise in the water level of the pools so as to further facilitate terrace formation. Since the precipitation of halite in the spring pools at Dallol is an easily reversible phenomenon (and rapidly changes to dissolution), terraces do not exhibit steady state, explaining the rapid changes that can be observed from one day to the next.

Widely described as small-scale morphologies in geothermal travertines, terraces have a key role as suitable environments for hosting living microorganisms, such as cyanobacteria and eukaryotic algae, and as a repository of fossilized microbial life. These functions, though greatly reduced in extremely harsh environments, may be present in such morphologies at Dallol.

3.2.3. Salt mushroom- and artichoke-like structures. Irregular, subcircular mushroom- and artichoke-like structures (Fig. 15) are among the characteristic salt (halite- 


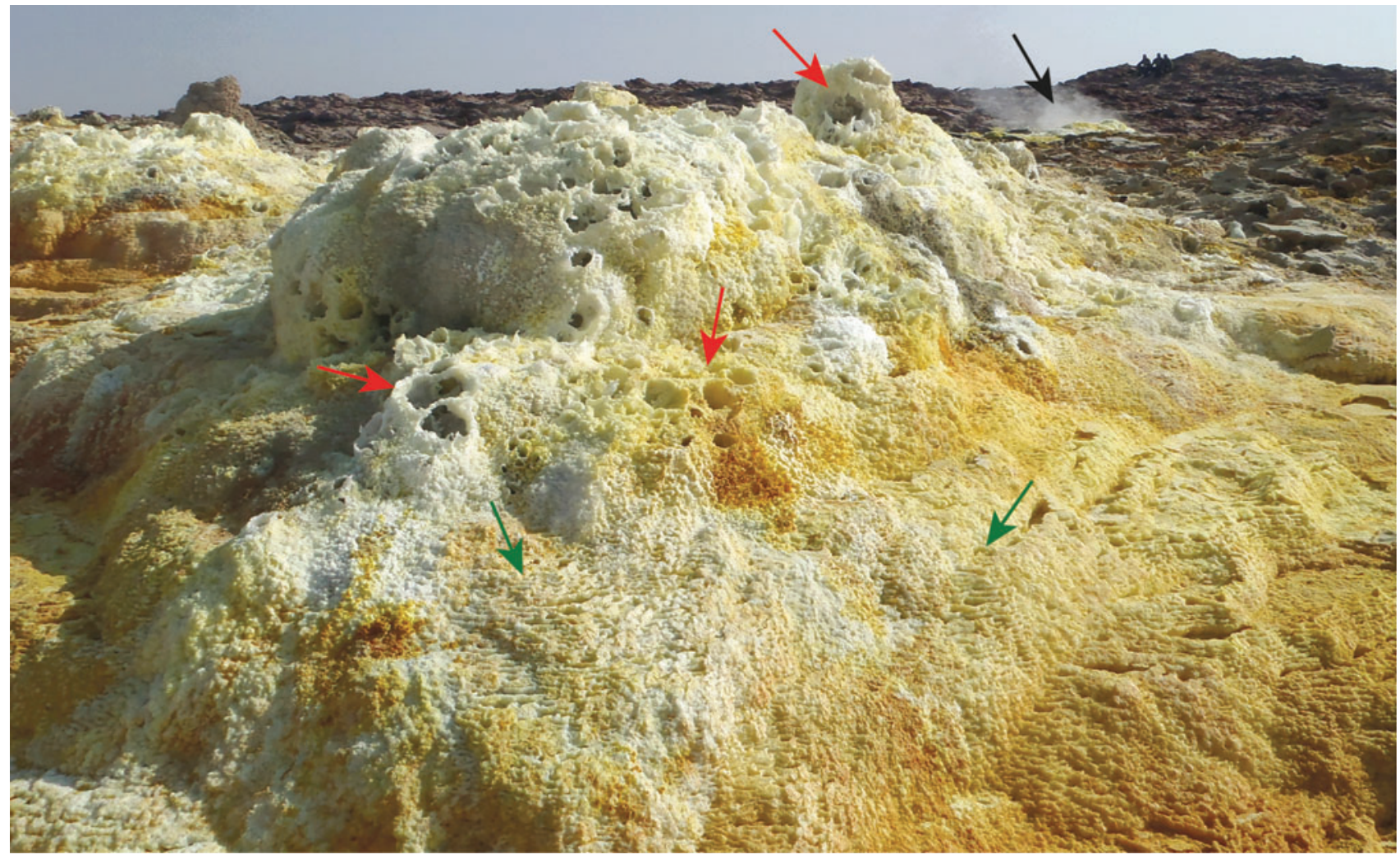

FIG. 12. Characteristic multivented spring mound with several fluid and gas escape features (red arrows) at the Dallol Hot Springs site. Note the base of the large mound dominated by microterraces (green arrows). Here the color ranges from white to yellow and red-orange to dark brown. Note the $\mathrm{H}_{2} \mathrm{~S}-\mathrm{SO}_{4}-\mathrm{H}_{2} \mathrm{O}$-dominated gaseous emission (black arrow). Field of view $\sim 3.7 \mathrm{~m}$.

dominated) morphologies of Dallol, where they emerge from dry shallow pools between the south and the central area of the volcano. With diameters that can reach (and exceed) $1.5 \mathrm{~m}$, these salt mushrooms abound in the bottoms of shallow pools, occurring both as single and composite structures. Mushroom caps have irregular forms with raised edges and depressed central areas that presumably depend upon their stage of growth. Closer inspection of their upper surfaces shows concentric rings likely produced during growth. Significantly smaller than the mushroom-like structures, the artichoke-like structures have typical sizes of about $10-15 \mathrm{~cm}$ and may represent the early stages of development of the mushrooms. Robust fringes, presumably produced during their development, crown the artichokelike structures.

Salt morphologies similar to mushrooms and artichokes have been described from other hypersaline settings, such as near the shoreline of the Dead Sea (Talbot et al., 1996). Large salt (gypsum and halite) mushrooms have also originated in shallow saline lakes (salares) of the Atacama region, where the selenite crystals composing their internal structure trap an abundance of bacterial cells and organic matter (Barbieri et al., 2009).

3.2.4. Salt rims. A number of open fissures or small gas pipes or escape structures with single or coalescent circular sections (average diameter: $7-8 \mathrm{~cm}$ ) have been observed on the salt substrate of the Dallol caldera (Fig. 16). Thin (a few millimeters thick), fragile white salt rims forming small dome structures can be observed growing around these fissure openings. The white salt rims are composed of pure sodium chloride in the form of halite. These structures develop high cylindrical or semicylindrical tubes of several centimeters in height. Most of them are well preserved, although some display an opening produced by their broken upper surface (Fig. 16C). These halite salt rims form during vapor emission from active small-sized vents and the concomitant direct precipitation of salts (e.g., Talbot, 2008).

Salt rim structures similar to those described herein, but with a different genesis, have been reported in a few restricted desert areas such as the Cordillera de la Sal in Chile, the Qarhan Salt Lake in China, and the gypsum and anhydrite deposits of the Neuquen Basin in Patagonia, Argentina (e.g., Stoertz and Ericksen, 1974; De Waele and Forti, 2010, and references therein). The salt rims and blisters in Chile are also made of pure halite and develop on the salt crust of the Atacama Desert, and have been interpreted to form during cycles of ephemeral condensation-evaporation processes occurring at small orifices at the interface between the salt surface and the atmosphere. This usually occurs immediately after very short episodes of rain.

3.2.5. Climate and vegetation. The Danakil Depression and, in particular, the Dallol area are characterized by consistently very hot climatic conditions with extremely limited rainfall. These persistently extreme temperatures 
FIG. 13. Field of meter-scale relict hydrothermal mounds and cones $(\mathbf{A}$, B). In (A), note the active Dallol Hot Springs center in the background (black arrow).
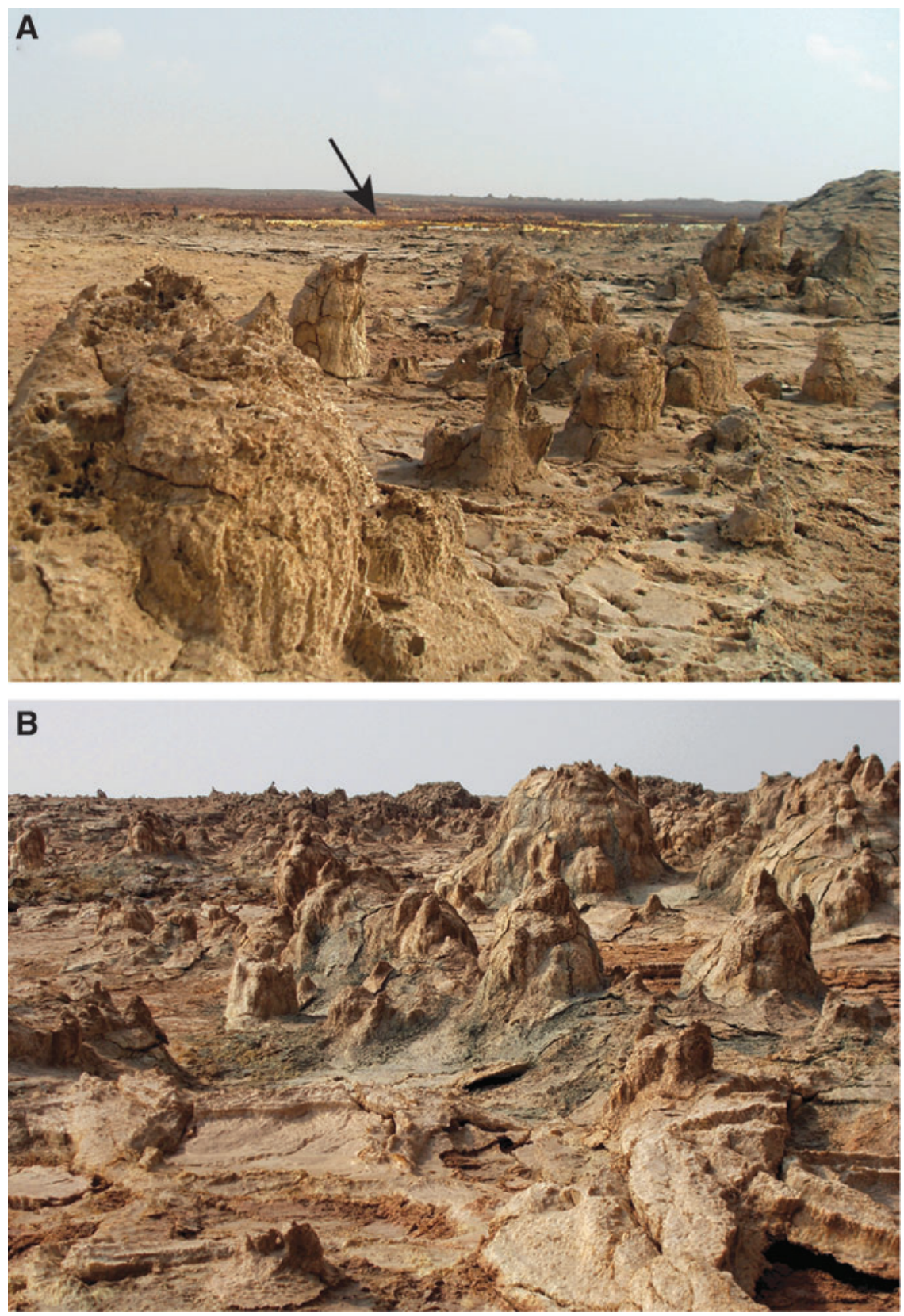

and low precipitation gradients seem intensified by a combination of factors such as the low latitude of the locality (latitude: $\left.14.14^{\circ} \mathrm{N}\right)$, its altitude below sea level $(\sim 124 \mathrm{~m}$ b.s.1.), and the intense geothermalism and active volcanism.

The daily average temperature on the salt plain during winter is consistently above $30^{\circ} \mathrm{C}$ and above $34-36^{\circ} \mathrm{C}$ on the Dallol area; in both areas, however, daytime temperatures routinely exceed $40^{\circ} \mathrm{C}$. Summer temperatures can easily rise to $50^{\circ} \mathrm{C}$ and above, especially in the Dallol area (during one field campaign conducted in October 2013, we registered daytime temperatures of $54^{\circ} \mathrm{C}$ ). Average annual rainfall is between less than 50 and $200 \mathrm{~mm}$ per year but is highly variable from year to year, always below $400 \mathrm{~mm}$ per year. An APCE-FWS-20 weather station (PCE Instruments) has been installed in the Dallol hydrothermal area $\left(14^{\circ} 14^{\prime} 18.15^{\prime \prime} \mathrm{N}\right.$, $40^{\circ} 17^{\prime} 53.76^{\prime \prime} \mathrm{E}, 89 \mathrm{~m}$ b.s.1.) and its mast located $50 \mathrm{~cm}$ from the ground in order to record environmental parameters such as air pressure, air temperature, humidity, and wind speed near the ground surface. These parameters were monitored in January 2017 during four consecutive days at 10:00 am, 11:00 am, and 12:30 pm. The maximum air temperature recorded was $45^{\circ} \mathrm{C}$ (at $12: 30 \mathrm{pm}$ ) with a corresponding humidity of $29 \%$ and wind speed of $29 \mathrm{~km} / \mathrm{h}$. Humidity is related to temperature and wind speed such that high air temperatures and wind speeds correspond to lower humidity.

The region, having the highest average daily and monthly temperatures in the region, can be considered the end member of the hyperarid desert climate and is classified within the BWh hot desert climate Köppen-Geiger climate zone (see Pedgley, 1967; Warren, 2016). Due to its hot climate and the limited annual rainfall, the Danakil region including the Dallol area, is known as the hottest place 

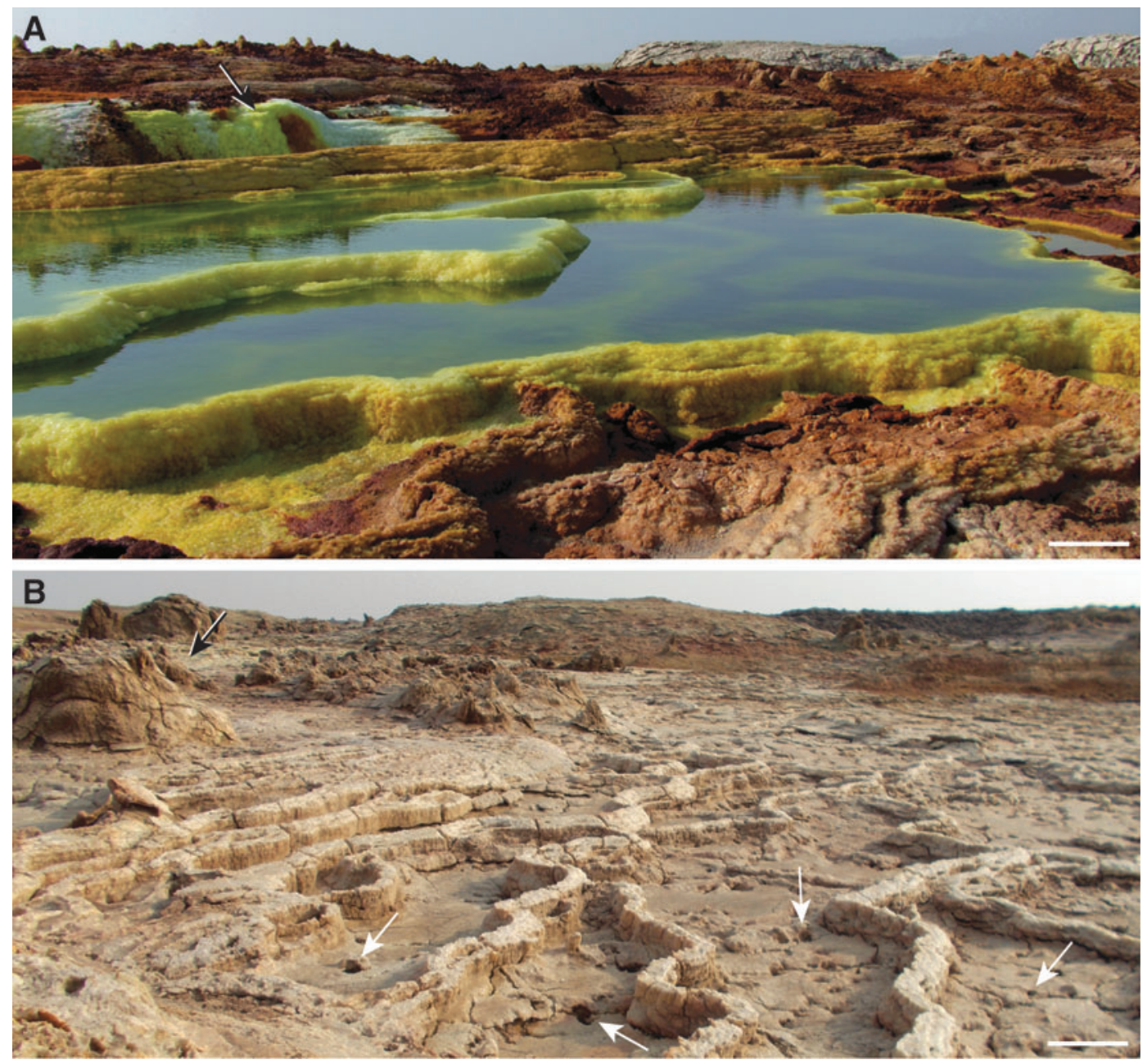

FIG. 14. Panoramic view of active (A) and inactive (B) terrace morphologies at the Dallol Hot Springs site. Meter-scale terraces consisting of halite (A) and/or halite-anhydrite (B) and originating from the slope of hot spring mounds (black arrows). Note the fluid escape features exposed on the ground of the dried pools (white arrows). Scale bars: $40 \mathrm{~cm}(\mathrm{~A})$ and $20 \mathrm{~cm}(\mathrm{~B})$.

on Earth, giving rise to deserted and often toxic (highly acidic and $\mathrm{H}_{2} \mathrm{~S}$-, $\mathrm{SO}_{4^{-}}$, and $\mathrm{CO}_{2}$-rich) environments with largely undocumented, rare endemic fauna and flora and sparse nomadic villages. Nonetheless, in the last decade, exploration and mining activities, together with the need for labor and the increasing presence of tourists, have resulted in the Hamed'Ela village (approximately $10 \mathrm{~km}$ southwest of the Dallol caldera), previously occupied only during the cold season, becoming permanently populated.

\section{Dallol Geothermal Field in an Astrobiological Perspective}

Terrestrial hydrothermal springs have long been considered among the most important environmental analogs in the search for life traces on early Earth and Mars (e.g., Walter and Des Marais, 1993). Their importance includes geological and geomorphological structures, mineral precipitation and alteration features that may ultimately lead to biosignature preservation (Schulze-Makuch et al., 2007; Allen and Oehler, 2008; Pondrelli et al., 2015; Ruff and Farmer, 2016; Barbieri and Cavalazzi, 2018). The exploration of terrestrial analogs can provide insights into the possible presence and nature of spring deposits on Mars, as well as help develop techniques for identifying them from remote sensing data and thereby define the future of astrobiological research.

Despite the high-resolution imaging and data presently available from other planetary bodies and that we expect to obtain from future exploration missions, the understanding of structures, processes, models, and habitats from Earth is still the most reliable means of interpreting planetary environments, especially in the case of other rocky planets. In the case of Mars, in particular, the convergence between what we know of the geological history of the planet and our growing understanding of the physical-environmental features of Dallol deserves a precise assessment. Current evidence suggests that martian hydrothermalism, which has been recognized in several regions of the planet, is either related to subaerial processes type and associated with phenomena of volcanism (volcanic edifices, basaltic deposits in the vicinity, etc.) or caused by impact cratering processes. Considering also the presence of evaporites, we find an environmental setting that is extraordinarily similar to the present situation in the Dallol volcano. 

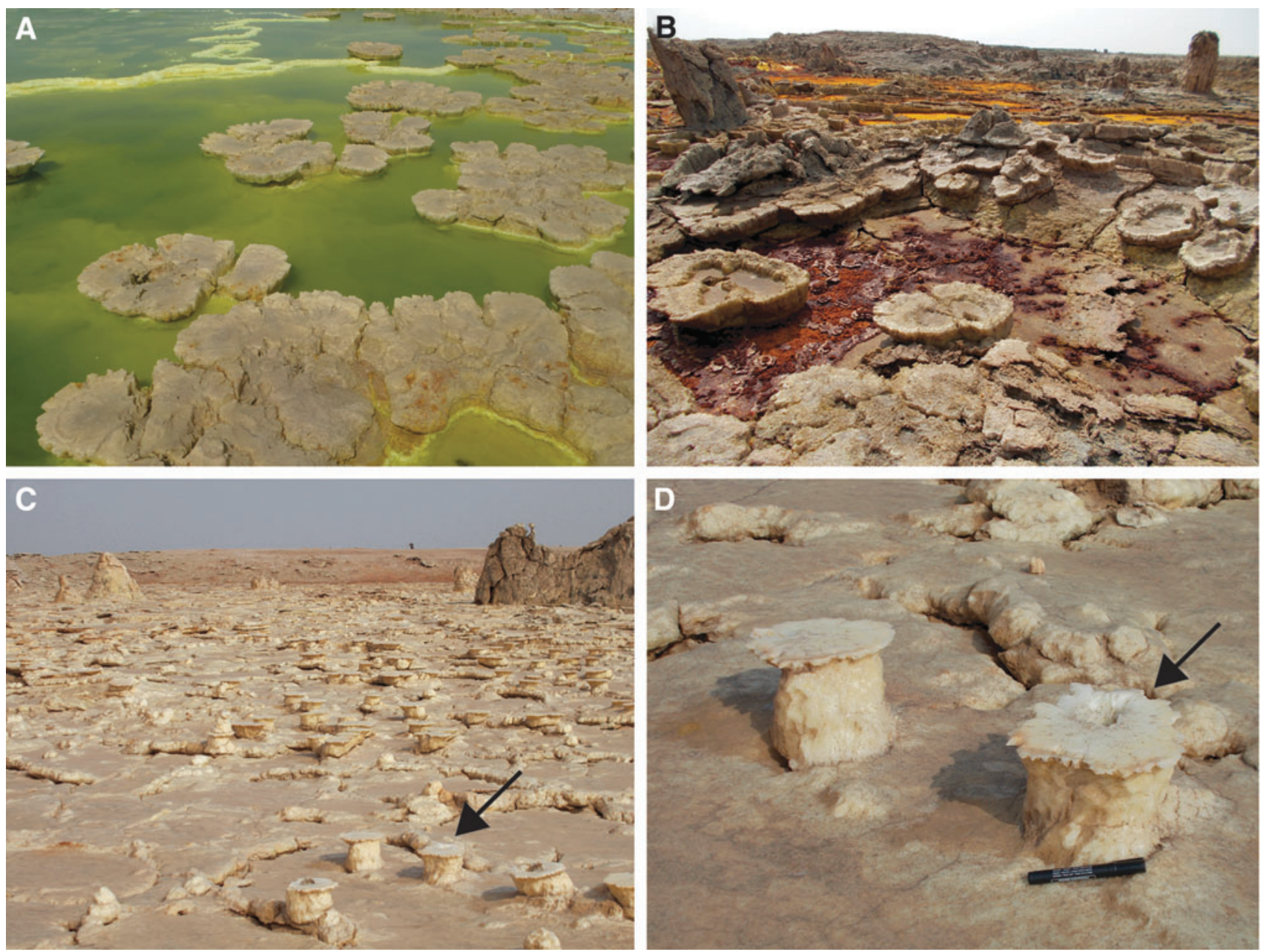

FIG. 15. (A-B) Active mushroom-like structures (field of view ca. $4 \mathrm{~m}$ ) and related relict morphologies (field of view $c a$. $5 \mathrm{~m}$ ), respectively. (C) Field of relict artichoke-like structures. The black arrow in (C) is detailed in (D). In (D) the marker for scale measures $13.5 \mathrm{~cm}$.

Therefore, the direct study of hydrothermal systems such as the extreme acidic and hypersaline Dallol Hot Springs center can have strategic importance for astrobiology since it allows the investigation of surface hydrothermal systems with similarity to those strongly suspected on Mars.

\subsection{Relevance of hydrothermal systems in astrobiology}

Hydrothermal systems are considered among the earliest habitable environments (Nisbet and Fowler, 1996; Arndt and Nisbet, 2012); indeed, hydrothermal systems associated with either submarine volcanic activity or terrestrial (subaerial) hot springs may have functioned as the environment in which life arose and, therefore, hosted the first living communities (Arndt and Nisbet, 2012; Grosch and Hazen, 2015; Djokic et al., 2017). This is supported by evidence from a number of scientific domains. The plurality of chemistries and hydrodynamic conditions near hydrothermal systems can create a range of gradients in, for example, temperature, $\mathrm{pH}$, salinity, redox conditions, elemental fluxes, and fluid dynamics (Russell et al., 2010, 2014), thus forming a range of microcosmic to macrocosmic disequilibrium systems. When life originated on Earth (more than 3.5 billion years ago), the environmental conditions at both planetary and local scale were profoundly different from those of the present (Cavalazzi et al., 2018) and suggest that the earliest life inhabited extremophilic niches that were exclusively anaerobic, (hyper)thermophilic, and metal-saturated (Frausto da Silva and Williams, 2001; Saito et al., 2003; Gaucher et al., 2010). Enzymatic and phylogenetic approaches consistently estimate that early life would have inhabited a thermophilic setting (Nisbet and Fowler, 1996; Gaucher et al., 2010) which, when viewed through the spectrum of ocean chemistries expected for the early, anaerobic Earth, suggests further that the environment was necessarily rich in metal cations (Frausto da Silva and Williams, 2001), hence the suggestion of hydrothermal systems.

The diversity of habitats present in the Dallol hydrothermal springs, together with the requirements in terms of mechanisms and biochemical demands of life to adapt to this most extreme environment, allow this unique place to serve as a natural laboratory to explore environments for early life, and possible environments in which extraterrestrial life may exist. The Dallol hydrothermal field encompasses a unique geological and active geodynamic setting involving 

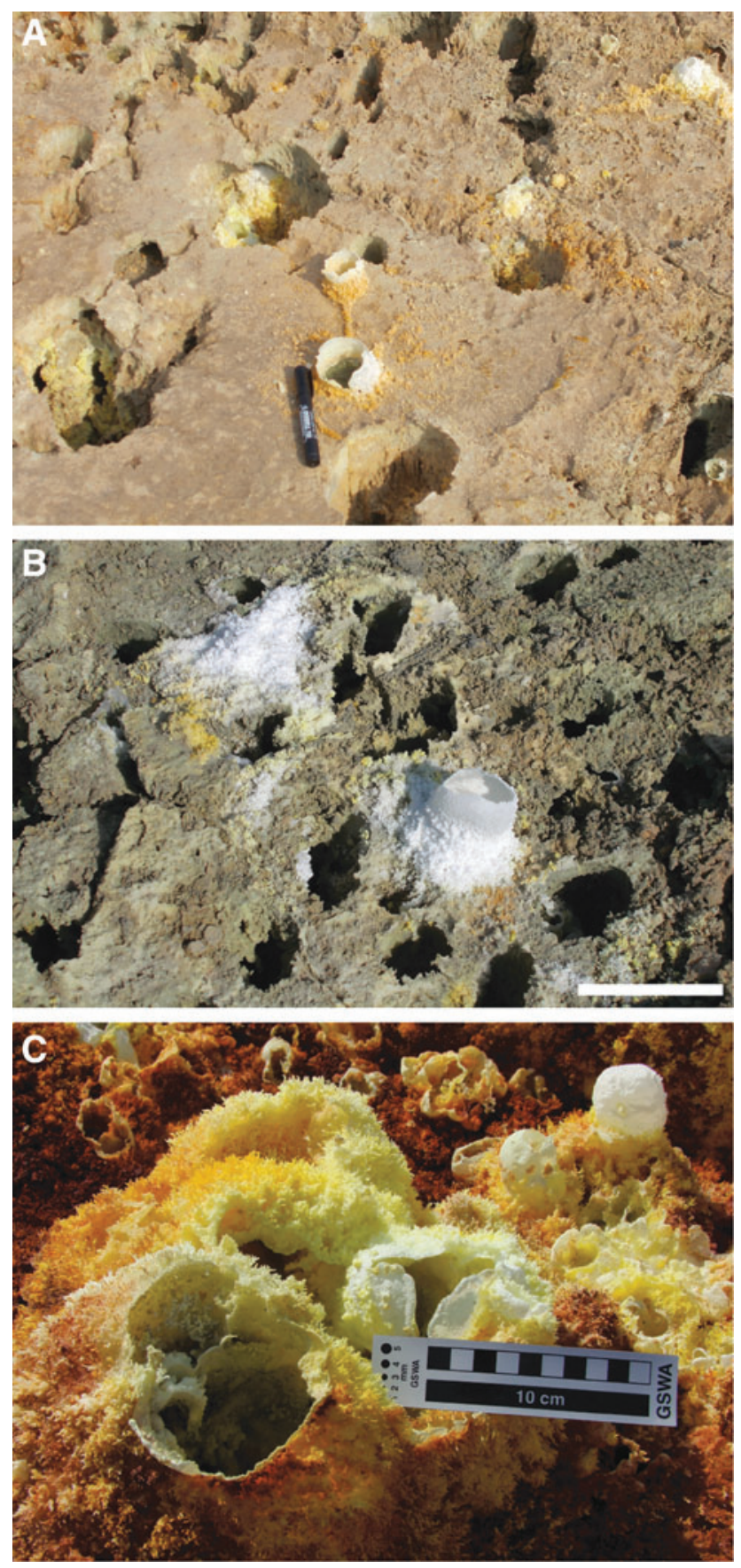

FIG. 16. White halite salt rims (few $\mathrm{mm}$ in thickness) growing around cylindrical openings (small vents, gas escape structures) on the salt bedrock (A-B) and dried pool floors (C), locally forming bubbles, forms as a result of vapor emission and salt precipitation. Note the orangeyellowish fine crystals growing around the base of most of the salt rims and the globular deposits around the base of the small halite conduits. (A) Marker for scale: $13.5 \mathrm{~cm}$. (B) Scale bar: $10 \mathrm{~cm}$.

the breakup of a continent, incipient ocean formation and volcanism, and thus the coexistence of many natural physical extremes for life (e.g., temperature, $\mathrm{pH}$, salinity, metal concentration). These characteristics, the defining parameters of a locality that is detectable from space, make sites such as this a potential target for a geologically interesting landing site of astrobiological relevance.

\subsection{Extremophiles of geothermal systems}

The first thermophilic microorganisms were discovered over 50 years ago in the hot springs of Yellowstone National Park (Brock, 1967). Since then, abundant microbial activity and a number of thermophiles and hyperthermophiles have been described and identified from a variety of geothermal environments (e.g., Vieille and Zeikus, 2001; Amils et al., 2007b; Barbieri et al., 2014). The best-known and most closely studied geothermal fields are in North and South America (e.g., Yellowstone National Park, USA; El Tatio geothermal field, Chile; Laguna Pastos Grandes, Bolivia), Iceland (e.g., Geysir and Krisuvik hot springs), New Zealand (e.g., Taupo Volcanic Zone), Japan (e.g., Nakabusa, Nagano Prefecture), Italy (e.g., Solfatara fumarole), and Russia (e.g., Kamchatka geothermal field).

Although studies have elucidated how extremophiles manage gene, protein, membrane, and nucleic acid structures (e.g., extremolytes) in extreme or stressed conditions (e.g., Vieille and Zeikus, 2001; Babu et al., 2015), there is not as yet a comprehensive understanding of the principles of survival and adaptation, such as thermostability or homeostasis, that extremophiles use in order to conserve their ecologies.

Geothermal regions including active marine hydrothermal vents and subaerial volcanic environments (e.g., hot springs, geysers and exhalations of hot vapors and gas, solfataric fields) pose more than one environmental extreme yet are colonized by metabolically diverse microorganisms. The microbial communities within the marine and subaerial environments are distinctly different due to the different physical and chemical parameters of their settings. Specific archaeal and bacterial groups show strong biases in environmental preferences, particularly based on sulfur cycle chemistry and pH (Teske, 2009). Hydrothermal waters usually show high concentrations of many elements (e.g., $\mathrm{Na}, \mathrm{K}, \mathrm{Fe}, \mathrm{Cu}, \mathrm{Au}$ ) and can be highly supersaturated with respect to a variety of minerals and mineral deposits that may originate in these environments (e.g., Simmons et al., 2005).

Subaerial hydrothermal systems are the product of subsurface geological processes, which result in reduced chemical species including sulfur and iron that become acidic due to proton-releasing oxidation reactions. The microbial diversity of hydrothermal soils (e.g., hot springs) is diverse and includes chemolithoautotrophic (obtaining energy from the microbial oxidation of inorganic compounds), thermophilic microorganisms that can also survive at low $\mathrm{pH}$ (acidophilic), such as the sulfur-oxidizing archaea (including genera Acidianus, Desulfurolobus, Metallosphaera, Solfolobus, Picrophilus, and Desolfurococcus) (Schleper et al., 1995; Kurosawa et al., 1998; Simmons and Norris, 2002; Dinarieva et al., 2010). For example, Picrophilus oshimae and Picrophilus torridus from solfataric sites in northern Japan grow optimally at pH $0.7\left(60^{\circ} \mathrm{C}\right)$ (Schleper et al., 1995). In contrast, deep-sea hydrothermal systems consist of hydrothermally heated rock materials (e.g., black smokers) in contact with seawater (3-5\% salt concentration), which buffers the protons 
released by sulfur oxidation reactions, resulting in $\mathrm{pH}$ values between 5 and 8.5 (Stetter, 1999).

4.2.1. High-temperature environments and (hyper)thermophiles. Because of their small size, microorganisms have developed special adaptation mechanisms to regulate differences between their internal temperatures and those of the external milieu.

To address the problem of DNA denaturing (i.e., the formation of two single strands), thermophiles depend on protein-DNA interaction and solutes. The thermostability of the DNA double helix is due to DNA interactions with double-stranded DNA-binding proteins similar to histones (Charlier and Droogmans, 2005). The accumulation of organic osmolytes, such as 2,3-diphosphoglycerate also plays a role in stabilizing the secondary structure on the DNA helix (Santos and da Costa, 2001); however, above $90^{\circ} \mathrm{C}$, DNA damage still occurs at a 1000 -fold higher rate than at $25^{\circ} \mathrm{C}$. Hyperthermophiles have, therefore, developed efficient DNA repair mechanisms, which are facilitated by having numerous copies of their genome. For example, experimental works with the hyperthermophilic Pyrococcus furiosus have demonstrated that the enzyme reverse gyrase counteracts the effect of DNA melting (Heine and Chandra, 2009).

Thermophiles have also evolved thermostable proteins, which have increased numbers of large hydrophobic residues, disulfide bonds, and ionic interactions that make them less liable to denature when exposed to high temperatures. Chaperone proteins, which are produced during heat shock, also play important roles in enhancing the thermostability of proteins (Schlee et al., 2001). High temperature also affects membrane fluidity, which is essential for cell structure and cellular processes. The mechanism of maintaining cell wall integrity differs between bacteria and archaea; however, both depend upon maintaining a liquid crystal state at high temperatures. For example, the bilayer, in hyperthermophilic archaea, is crosslinked with C40 transmembrane phytanyl chains (Comita et al., 1984).

4.2.2. Acidic environments and acidophiles. Acidophilic microorganisms grow optimally at low $\mathrm{pH}(<3)$. To grow in such conditions, the microorganisms must maintain a $\mathrm{pH}$ gradient across the cellular membrane while still producing ATP (adenosine triphosphate), which is important for transporting energy within the cell (for review, see BakerAustin and Dopson, 2007). A variety of pH-homeostatic mechanisms are employed to restrict protons entering the cells via the cytoplasmic membrane and purging protons and mitigating their effect in the cytoplasm. To help maintain a $\mathrm{pH}$ gradient across the cell membrane, acidophiles have a highly impermeable membrane and positive delta $\Psi$ (opposite to neutrophiles), which inhibits the influx of protons using a chemiosmotic barrier (Suzuki et al., 1999). Protons are also removed from the cytoplasm by a proton translocation system that removes protons to access (Michels and Bakker, 1985). If protons penetrate the cell membrane, a range of intracellular mechanisms are employed to limit biological damage. This includes a range of cytoplasmic buffering molecules including basic amino acids that are able to maintain homeostasis by buffering (Castanie-Cornet et al., 1999). DNA and protein damage associated with acidic conditions can be repaired using chaperone proteins (Jerez et al., 1988).

Most acidophiles obtain energy from reduced mineral compounds; however, at the Río Tinto planetary analog site, some are reported to obtain energy from sunlight (Amils et al., 2007a). In nature, acidophiles have commonly been observed to oxidize elemental sulfur in hydrothermal vents and to oxidize sulfidic minerals in metallic sulfidic mines in order to obtain energy. It is interesting that many acidophiles will cause and/or contribute to acidity of their habitat through, for example, oxidizing sulfur and producing sulfuric acid as a by-product. Low microbial diversity systems oxidizing reduced sulfur have been observed in the Laguna Caliente ultra-acidic volcanic lake (Hynek et al., 2018).

4.2.3. Salt environments and halophiles. Halophilic microorganisms grow in high salt concentrations from $10 \%$ salinity to saturation levels and can even survive within salt crystals. Halophilic archaea have been isolated from salt crystals and evaporite deposits in the rock record (e.g., Vreeland et al., 2000, 2007; Schubert et al., 2010; Fendrihan et al., 2012; Stivaletta et al., 2012). Experiments have demonstrated that halophilic microorganisms entombed in halite are able survive detrimental exposure effects associated with the surface of Mars (UV radiation, cold temperatures, and desiccation) and specific terrestrial conditions (e.g., Fendrihan et al., 2009; Mancinelli, 2015). On Earth, halophiles have been isolated from a wide range of environments, among which are salt marshes, undersea salt domes, and subterranean halite deposits from evaporated ancient seas.

To cope with the osmotic stress associated with high salt concentration, microbes have developed two general methods, the salt-in and the salt-out approaches (Oren, 2006). The salt-in approach involves a high concentration of ions accumulating within the cells, for example $\mathrm{K}^{+}$, which generates an osmotic equilibrium with the outside environment (Vreeland, 1987). For this to occur, the proteins within the cells need to adapt to survive the high salt concentration; for example, these proteins require a higher number of ionic bridges. In contrast, the salt-out strategy involves the cells actively pumping salt out of the cell to prevent cell damage. To prevent an osmotic pressure developing across the membrane, the cell produces compatible solutes, such as amino acids and sugars (Kempf and Bremer, 1998).

4.2.4. Polyextremophiles. Previous investigations have isolated thermo-acidophilic microorganisms from solfataric fields, which are acidic, high-temperature, sulfate-rich environments (e.g., Segerer et al., 1998; Hedlund et al., 2015; Johnson and Aguilera, 2016). A comparison of genomes from the thermo-acidophilic genera Picrophilus, Thermoplasma, and Sulfolobus has demonstrated a number of features that may contribute to the survival of microorganisms in high-temperature acidic conditions, for example novel enzymes (e.g., Johnson and Aguilera, 2016). Although halophilic alkali-thermophiles have been isolated and their physiology characterized (Mesbah and Wiegel, 2012), there has been little previous work focusing on the adaptation of microbial communities to the combined effects of high 
temperature, high salt, and acidic stresses. The Dallol Hot Springs present a unique opportunity to study the microorganisms that grow at high temperature and salinity, and low $\mathrm{pH}$, particularly in discovering novel microorganisms, metabolisms, and adaptation mechanisms.

\subsection{Terrestrial analogs for Mars science}

Geomorphological and mineralogical data collected by martian missions (orbiters and landers) allows the reconstruction of conditions that, based on terrestrial evidence, can be traced back to hydrothermal activity and volcanism (e.g., Dohm and Tanaka, 1999; Schulze-Makuch et al., 2007; Squyres et al., 2008; Rodríguez and van Bergen, 2016; Ruff and Farmer, 2016; Michalski et al., 2017). The detection of opaline silica deposits in Meridiani Planum (Glotch and Bandfield, 2006) and Gusev Crater (Squyres et al., 2008; Ruff et al., 2011) has generated a great astrobiological interest. Although silica in hydrothermal systems can often be related to abiotic processes, specific silica morphologies, such as nodules and digitations, may require the influence of organisms to develop (Ruff and Farmer, 2016). A further key role played by hydrothermal silica is related to its unparalleled ability for preserving different types of biosignatures (morphological, geochemical, geobiological), even in very ancient terrestrial settings, which is particularly important considering the apparent abundance of hydrothermal environments (one of the presumable cradles of life) on the early Earth and Mars (e.g., Cavalazzi et al., 2018).

Similarly to hydrothermal sites, other surface environments may imply rock-water interactions and the formation of hydrated minerals, as in the case of hypersaline environments. Although characterized by severely limiting factors, hypersaline environments do not prevent the development of prokaryote diversity (e.g., Ventosa et al., 2015). Especially with regard to Mars where, similarly to Earth, there are widespread sulfate- and other salt-bearing deposits, geological and compositional data suggest an origin from evaporitic environments (i.e., a genesis under aqueous conditions) (e.g., Hynek et al., 2015). Hypersaline systems may thus well be considered a primary hydrological target for studies of martian habitability (Barbieri, 2013).

Among the many kinds of hypersaline settings, the most saline and the most acidic aqueous environments are considered particularly challenging, since they impose the requirement for specific biotic adaptations for withstanding a number of physicochemical stresses. These environments would, therefore, be counted among the most extreme on the planet. In hot and extremely acidic hypersaline brine pools at Dallol, the formation of exhalative salt mounds produced by fluid migration through vertical conduits at the ground-air interface takes place. This is a salt volcano environment in which high-density brines, extreme acidity hot waters and gases combine to form a unique hydrothermal circulation system (Hovland et al., 2006). In the case of martian salts, the interaction between fluids (including groundwater and hot hydrothermal fluids) and igneous rock (basalts) may have had a primary role in their genesis (Bullock and Moore, 2004), and therefore the Dallol salt volcano can be considered a reliable terrestrial analog of martian environments (Cavalazzi et al., 2014).
This gives the site a key role in the search for the limits of biotic tolerance and for the preservation of organic compounds and any other biosignature potentially deliverable to the fossil record. In this regard, the survival of cells over millennia in terrestrial sedimentary rocks would have important implications for the search for life on other planets where structures of sedimentary origin exist (Squyres and Knoll, 2005).

The qualitative and quantitative increase of data coming from Mars has enabled an almost Earth-like approach for studying its geoenvironmental evolution. For example, a direct relationship between spring and salt precipitation has been proposed for explaining their combined recovery (Rossi et al., 2008). For the particularly well-studied case of Arabia Terra, the morphological expression of the putative spring deposits consists of crater bulges, hot spring mounds and salt flats in the craters and plateau, respectively (Franchi et al., 2014; Pondrelli et al., 2015) (Fig. 17). In this region of Mars, fluid expulsion features such as fissure ridges, ponds, and mounds have been documented associated with light-toned layered deposits. Polyhydrated sulfates have been detected both in mounds and salt flats, thus constraining the interpretation of such deposits to evaporites. Such an interpretation is consistent with the presence of a meter-scale polygonal pattern disrupting the layers. The dissolution of these deposits, another characteristic suggestive of evaporitic composition, is suggested by morphologies such as rounded shapes, sinuous margins, and quasi-circular depressions. On the plateau, salt flats are interlayered with cross-bedded duneforms interpreted as eolian deposits. The depicted scenario is a desert environment dominated by eolian processes with episodes of water upwelling and spring deposits laterally associated to salt flats. These morphological and compositional features are comparable to the salt deposits in the Dallol area. One should note, though, that the scale of their martian counterparts is one to two orders of magnitude larger; this is true for several martian landforms. Arabia Terra connects the highlands and the lowlands of Mars with relatively low slopes over a wide area, and it is thought to have been formed by a groundwater-dominated hydrological system (AndrewsHanna et al., 2007, 2010; Andrews-Hanna and Lewis, 2011; Zabrusky et al., 2012). The geodynamic setting is thus not directly comparable to the Dallol area, since no rift system is present in Arabia Terra, nor is active local volcanism clearly documented at the time of the deposition of the sulfatebearing deposits. Nonetheless, a relation between tectonic fractures acting as preferential fluid pathways, fluid upwelling, and evaporite precipitation appears to be present. The sulfate-bearing deposits rest unconformably on top of a probable basaltic succession. An eventual link between fluid upwelling and hydrothermal processes cannot yet be ruled out, nor demonstrated, based on available data. Although an obvious coeval individual volcanic edifice is missing, basaltic emplacement is recorded extensively in the stratigraphic record of Arabia Terra, and it cannot be excluded that some episodes were partly coeval with the sulfatebearing deposits. Moreover, impact cratering can also trigger hydrothermal activity (e.g., Abramov and Kring, 2005), with magnitude and length of such activity scaled based on crater size. This could explain the difference in thickness of 

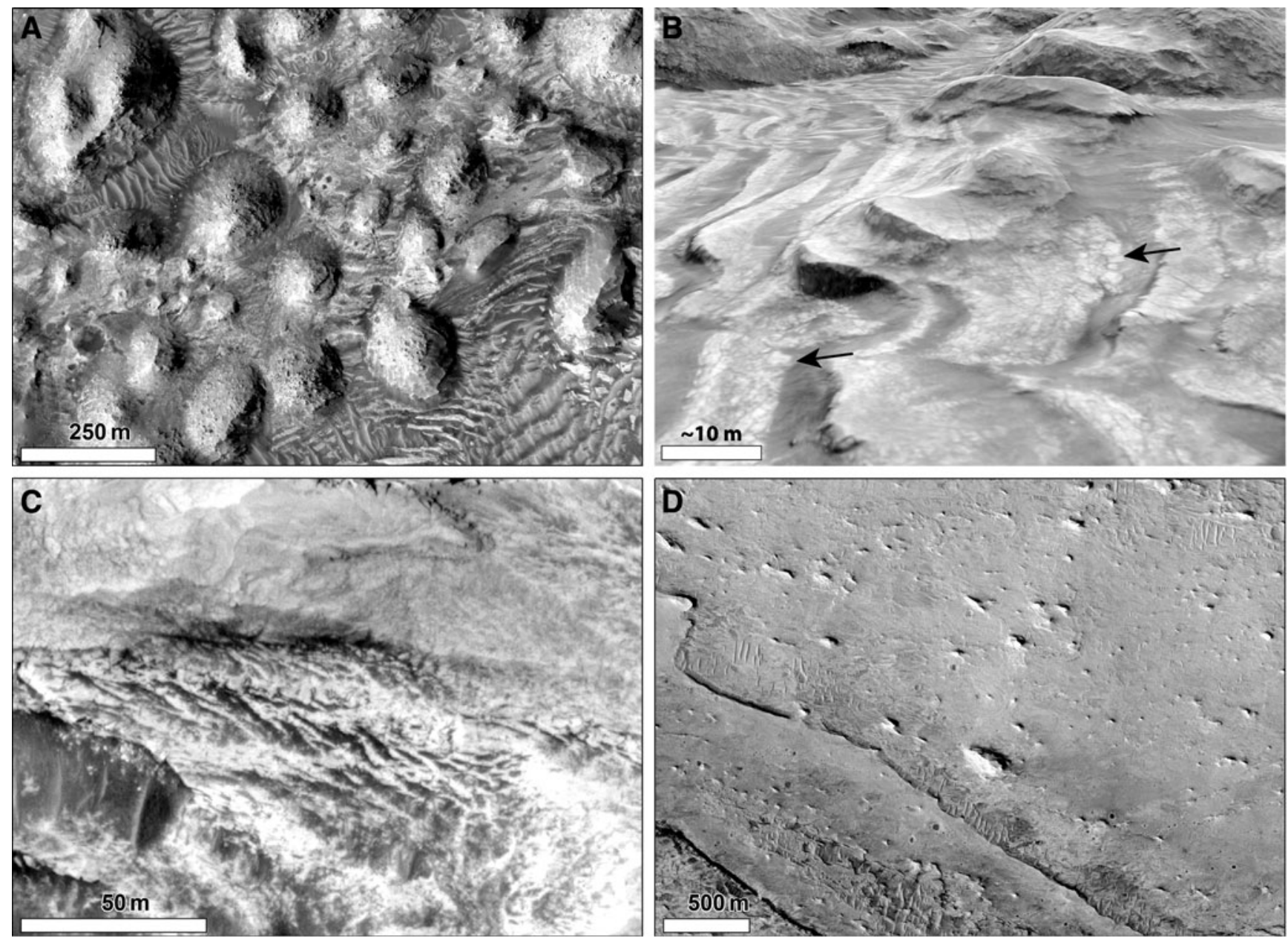

FIG. 17. Examples of possible martian analogs from Arabia Terra (Firsoff Crater) within light-toned, sulfate-bearing layered deposits. (A) Field of features interpreted as spring mounds (HiRISE image PSP_003788_1820). (B) Perspective view of the layered deposits in (A) disrupted in a polygonal pattern (arrows) (HiRISE DEM PSP_003788_1820/ ESP_020679_1820; no vertical exaggeration). (C) Cross-bedding interpreted to represent eolian duneforms on the basis of scale and lack of association with water-related morphologies (HiRISE image PSP_006623_1800). (D) Possible salt plain. The light-toned deposits are disrupted by polygonal patterns (HiRISE image ESP_013031_1800). Modified from Pondrelli et al., 2015.

the sulfate-bearing layered deposits that in the craters can reach up to thousands of meters whereas on the plateau it has been estimated around just a few tens of meters (Pondrelli et al., 2015).

\section{Conclusions}

The Danakil Depression is located in the northern Afar Region of Ethiopia near the borders of Eritrea and Djibouti. The famous British explorer Wilfred Thesiger described the place as "a land of death", which is a perfectly apt description for any outsider entering the region. This description not only applies to humans settled in the locality due to the high average temperatures but also to the very harsh conditions faced by the microbial life inhabiting the ecosystems of the area. The very extreme physicochemical parameters make this site a polyextremophilic environment with the potential to harbor, among others, acidophilic, thermophilic, and/or halophilic microorganisms and met- abolic networks. The physical and compositional features of the Dallol deposits, their mineralogies, sedimentary and alteration features, and their location in a region of basaltic volcanism of planetary-scale importance, are testament to the novelty of this extreme environment and its ability to host life-forms and to preserve biosignatures. It is therefore also a reliable analog to ancient martian environments and habitats. Deep investigation of the characteristics of this unique geological site will improve our understanding of the limits of life on Earth and inform the search for life on the Red Planet.

Extensive spring deposits associated with salt precipitation have also been noted in the martian terrane of Arabia Terra, where their morphological expression comprises spring deposits and salt flats in craters and on plateau similar to those found in the Dallol area. The geological similarities between the Dallol area and various potential hydrothermal systems on Mars indicate that this unique region presents an excellent planetary field analog for astrobiology. 
Recently, the Dallol geothermal area and its unique characteristics have been suggested as a geoheritage site, and a geoconservation strategy has been proposed (Asrat, 2018). We concur that, in light of ongoing and future astrobiological and planetary science programs and missions, this region should be considered a target for space strategy plans in Africa and protected as a planetary terrestrial analog.

\section{Authors' Note}

In memory of our colleague Bruno Capaccioni, Professor in Geochemistry and Volcanology at the Università di Bologna, who sadly passed away in 2016.

\section{Acknowledgments}

Barbara Cavalazzi acknowledges support by the International Cooperation Program between the Università di Bologna and the University of Mekelle. We are grateful to Franco Pirajno and an anonymous reviewer for taking the time to provide comments and suggestions. B.C. would like to kindly thank Ernesto Abbate (Università di Firenze), Judith Rendón, (Hospital of Mekele), Livia Mercatelli (International Office of the Università di Bologna), Solomon Hishe (University of Mekelle), Birhanu Berhe (Temesgen Pharmacy in Mekelle), Zablon Beyene and Mikael Tamrat (Zab Tours Ethiopia), Sister Laura and the Kidane Mehret Mission in Adwa, the Associazione Amici di Adua Onlus and volunteers Samantha, Marina, Serena, Alberto, Tommaso, and Daniele. Finally, but most importantly, B.C. would like to thank the Afars from Hamed'Ela village, who have always been very welcoming. This is a contribution to the Europlanet 2020 Research Infrastructure programme funded under the European Commission's Horizon 2020 programme (No. 654208).

\section{References}

Abbate, E., Bruni, P., and Sagri, M. (2015) Geology of Ethiopia: a review and geomorphological perspectives. In Landscapes and Landforms of Ethiopia, World Geomorphological Landscapes, edited by P. Billi, Springer Science+Business Media, Dordrecht, the Netherlands, pp 33-64.

Abramov, O. and Kring, D.A. (2005) Impact-induced hydrothermal activity on early Mars. J Geophys Res Planets 110, doi:10.1029/2005JE002453.

Acocella, V. (2006) Regional and local tectonics at Erta Ale caldera, Afar (Ethiopia). J Struct Geol 28:1808-1820.

Acocella, V. (2010) Coupling volcanism and tectonics along divergent plate boundaries: collapsed rifts from central Afar, Ethiopia. Geol Soc Am Bull 122:1717-1728.

Acocella, V. and Korme, T. (2002) Holocene extension direction along the Main Ethiopian Rift, East Africa. Terra Nova 14:191-197.

Allana Potash Corporation. (2011) Resource Report for the Danakhil Potash Deposit, Afar State Ethiopia, ERCOSPLAN Ingenieurgesellschaft (EGB 11-008), Germany.

Allana Potash Corporation. (2012) Dallol Potash ProjectDraft Environmental, Social and Health Impact Assessment Report, Environmental Resources Management (ERM) (ERM Southern Africa Project 0143047), South Africa.

Allen, C.C. and Oehler, D.Z. (2008) A case for ancient springs in Arabia Terra, Mars. Astrobiology 8:1093-1112.
Amils, P.R., Ellis-Evans, C., and Hinghofer-Szalkay, H.G. (2007a) Life in Extreme Environments, Springer, Dordrecht, the Netherlands.

Amils, R., González-Toril, E., Fernández-Remolar, D., Gómez, F., Aguilera, A., Rodríguez, N., Malki, M., García-Moyano, A., Fairén, A.G., de la Fuente, V., and Sanz, J.L. (2007b) Extreme environments as Mars terrestrial analogues: the Rio Tinto case. Planet Space Sci 55:370-381.

Andrews-Hanna, J.C. and Lewis, K.W. (2011) Early Mars hydrology: 2. Hydrologic evolution in the Noachian and Hesperian epochs. J Geophys Res Planets 116, doi:10.1029/ 2010JE003709.

Andrews-Hanna, J.C., Phillips, R.J., and Zuber, M.T. (2007) Meridiani Planum and the global hydrology of Mars. Nature 446:163-166.

Andrews-Hanna, J.C., Zuber, M.T., Arvidson, R.E., and Wiseman, S.M. (2010) Early Mars hydrology: Meridiani playa deposits and the sedimentary record of Arabia Terra. $J$ Geophys Res Planets 115, doi:10.1029/2009JE003485.

Arndt, N.T. and Nisbet, E.G. (2012) Processes on the young Earth and the habitats of early life. Annu Rev Earth Planet Sci 40:521-549.

Asrat, A. (2018) Potential geoheritage sites in Ethiopia: challenges of their promotion and conservation. In Geoheritage: Assessment, Protection, and Management, edited by E. Reynard and J. Brilha, Elsevier, Amsterdam, pp 339-353.

Babu, P., Chandel, A.K., and Singh, O.V. (2015) Extremophiles and Their Applications in Medical Processes, Springer, Cham, Switzerland.

Baker, V.R. (2014) Terrestrial analogs, planetary geology, and the nature of geological reasoning. Planet Space Sci 95:5-10.

Baker-Austin, C. and Dopson, M. (2007) Life in acid: pH homeostasis in acidophiles. Trends Microbiol 15:165-171.

Bannert, D., Brinckmann, J., Käding, K.C., Knetsch, G., Kürsten, M., and Mayrhofer, H. (1970) Zur Geologie der Danakil-Senke. Geol Rundsch 59:409-443.

Barberi, F. and Varet, J. (1971) The Erta Ale volcanic range (Danakil Depression, Northern Afar, Ethiopia). Bull Volcanol 34:848-917.

Barberi, F, Borsi, S., Ferrara, G., Marinelli, G., Santcroce, R., Tazieff, H., and Varet, J. (1972) Evolution of the Danakil Depression (Afar Ethiopia) in light of radiometric age determination. J Geol 80:720-729.

Barbieri, R. (2013) The role of terrestrial analogs in the exploration of the habitability of martian evaporitic environments. In Habitability of Other Planets and Satellites, edited by J.-P. de Vera and J. Seckbach, Springer, Dordrecht, the Netherlands, pp 163-180.

Barbieri, R. and Cavalazzi, B. (2018) Microterracettes in Sabkha Oum Dba (Western Sahara, Morocco): physical and biological interactions in the formation of a surface micromorphology. Astrobiology 18:1351-1367.

Barbieri, R., Cavalazzi, B., Stivaletta, N., and Capaccioni, B. (2009) Life at the extremes: physical environments and microorganisms in the Atacama region (Chile). GeoActa 2:141-153.

Barbieri, R., Cavalazzi, B., Stivaletta, N., and López-García P. (2014) Silicified biota in high-altitude, geothermally influenced ignimbrites at El Tatio Geyser Field, Andean Cordillera (Chile). Geomicrobiol J 31:493-508.

Barrat, J.A., Fourcade, S., Jahn, B.M., Cheminee, J.L., and Capdevila, R. (1998) Isotope ( $\mathrm{Sr}, \mathrm{Nd}, \mathrm{Pb}, \mathrm{O})$ and traceelement geochemistry of volcanics from the Erta'Ale range (Ethiopia). J Volcanol Geotherm Res 80:85-100. 
Beyene, A. and Abdelsalam, M.G. (2005) Tectonics of the Afar Depression-a review and synthesis. J Afr Earth Sci 41:4159.

Bonatti, E., Emiliani, C., Ostlund, G., and Rydell, H.S. (1971) Final desiccation of the Afar rift, Ethiopia. Science 172:468470.

Brinkmann, J. and Kürsten, M. (1970) Geological sketch map of the Danakil Depression, scale 1:250,000, Bunderanstalt für Bodenforschungen, Hanover, Germany.

Brock, T.D. (1967) Relationship between standing crop and primary productivity along a hot spring thermal gradient. Ecology 48:566-571.

Bullock, M.A. and Moore, J.M. (2004) Aqueous alteration of Mars-analog rocks under an acidic atmosphere. Geophys Res Lett 31:L14701.

Capaccioni, B., Vaselli, O., Moretti, E., Tassi, F., and Franchi, R. (2003) The origin of thermal waters from the eastern flank of the Dead Sea Rift Valley (western Jordan). Terra Nova 15: 145-154.

Carniel, R., Munoz, J.E., and Jones, J. (2010) A geophysical multi-parametric analysis of hydrothermal activity at Dallol, Ethiopia. J Afr Earth Sci 58:812-819.

Castanie-Cornet, M.P., Penfound, T.A., Smith, D., Elliott, J.F., and Foster, J.W. (1999) Control of acid resistance in Escherichia coli. J Bacteriol 181:3525-3535.

Cavalazzi, B., Barbieri, R., Hagos, M., Capaccioni, B., Agangi, A., Gasparotto, G., Palazzo, Q., Kiros, K., Glamoclija, M., and Rossi, A.P. (2014) Extreme among extremes: salt and sulphur springs of the Dallol (Danakil Depression, Ethiopia) and their astrobiological role. In Proceedings of the $14^{\text {th }}$ European Astrobiology Conference (EANA 2014), Edinburgh, UK.

Cavalazzi, B., Glamoclija, M., Brack, A., Westall, F., Orosei, R., and Cady, S.L. (2018) Astrobiology, life formation and planetary exploration. In Planetary Geology, edited by A.P. Rossi and S. van Gasselt, Springer Praxis Books, Cham, Switzerland, pp 347-367.

Cavalazzi, B., and Westall, F. (2019) Biosignatures for Astrobiology. Springer International Publishing.

Charlier, D. and Droogmans, L. (2005) Microbial life at high temperature, the challenges, the strategies. Cell Mol Life Sci 62:2974-2984.

Chernet, T. (2011) Dallol: Phreatic Eruption in $1^{\text {st }}$ Week of January 2011, Research and Development Directorate, Ministry of Mines, Addis Ababa, Ethiopia.

Comita, P.B., Gagosian, R.B., Pang, H., and Costello, C.E. (1984) Structural elucidation of a unique macrocyclic membrane lipid from a new, extremely thermophilic, deep-sea hydrothermal vent archaebacterium, Methanococcus jannaschii. J Biol Chem 259:15234-15241.

Corti, G. (2009) Continental rift evolution: from rift initiation to incipient break-up in the Main Ethiopian Rift, East Africa. Earth Sci Rev 96:1-53.

Craig, T.J., Jackson, J.A., Priestley, K., and McKenzie, D. (2011) Earthquake distribution patterns in Africa: their relationship to variations in lithospheric and geological structure, and their rheological implications. Geophys J Int 185:403-434.

Darrah, T.H., Tedesco, D., Tassi, F., Vaselli, O., Cuoco, E., and Poreda, R.J. (2013) Gas chemistry of the Dallol region of the Danakil Depression in the Afar region of the northern most East African Rift. Chem Geol 339:16-29.

De Waele, J. and Forti, P. (2010) Salt rims and blisters: peculiar and ephemeral formations in the Atacama Desert (Chile). Zeitschrift für Geomorphologie 54:51-67.
Dinarieva, T.Y., Zhuravleva, A.E., Pavlenko, O.A., Tsaplina, I.A., and Netrusov, A.I. (2010) Ferrous iron oxidation in moderately thermophilic acidophile Sulfobacillus sibiricus N1T. Can J Microbiol 56:803-808.

Djokic, T., Van Kranendonk, M.J., Campbell, K.A., Walter, M.R., and Ward, C.R. (2017) Earliest signs of life on land preserved in ca. $3.5 \mathrm{Ga}$ hot spring deposits. Nat Commun 8: 15263.

Dohm, J.M. and Tanaka, K.L. (1999) Geology of the Thaumasia region, Mars: plateau development, valley origins, and magmatic evolution. Planet Space Sci 47:411-431.

Ebinger, C.J. and Casey, M. (2001) Continental breakup in magmatic provinces: an Ethiopian example. Geology 29:527-530.

Ebinger, C.J., Keir, D., Ayele, A., Calais, E., Wright, T.J., Belachew, B., Hammond, J.O.S., Campbell, E., and Buck, W.R. (2008) Capturing magma intrusion and faulting processes during continental rupture: seismicity of the Dabbahu (Afar) rift. Geophys J Int 174:1138-1152.

Fendrihan, S., Berces, A., Lammer, H., Musso, M., Ronto, G., Polacsek, T.K., Holzinger, A., Kolb, C., and Stan-Lotter, H. (2009) Investigating the effects of simulated martian ultraviolet radiation on Halococcus dombrowskii and other extremely halophilic archaebacteria. Astrobiology 9:104-112.

Fendrihan, S., Dornmayr-Pfaffenhuemer, M., Gerbl, F.W., Holzinger, A., Grösbacher, M., Briza, P., Erler, A., Gruber, C., Plätzer, K., and Stan-Lotter, H. (2012) Spherical particles of halophilic archaea correlate with exposure to low water activity-implications for microbial survival in fluid inclusions of ancient halite. Geobiology 10:424-433.

Franchi, F., Rossi, A.P., Pondrelli, M., and Cavalazzi, B. (2014) Geometry, stratigraphy and evidences for fluid expulsion within Crommelin crater deposits, Arabia Terra, Mars. Planet Space Sci 92:34-48.

Franzson, H., Helgadóttir, H.M., and Óskarsson, F. (2015) Surface exploration and first conceptual model of the Dallol Geothermal area, northern Afar, Ethiopia [\#11043]. In Proceedings World Geothermal Congress 2015, Melbourne, Australia.

Frausto da Silva, J.J.R. and Williams, R.J.P. (2001) The Biological Chemistry of the Elements, Oxford University Press, Oxford.

Garland, C.R. (1980) Geology of the Adigrat Area. Ministry of Mines, Addis Ababa Memoir 1:1-51.

Gaucher, E.A., Kratzer, J.T., and Randall, R.N. (2010) Deep phylogeny-how a tree can help characterize early life on Earth. Cold Spring Harb Perspect Biol 2, doi:10.1101/ cshperspect.a002238.

Glotch, T.D. and Bandfield, J.L. (2006) Determination and interpretation of surface and atmospheric Miniature Thermal Emission Spectrometer spectral end-members at the Meridiani Planum landing site. J Geophys Res Planets 111, doi: 10.1029/2005JE002671.

Grosch, E.G. and Hazen, R.M. (2015) Microbes, mineral evolution, and the rise of microcontinents-origin and coevolution of life with early Earth. Astrobiology 15:922-939.

Hedlund, A.P., Reysenbach, A.-L., Huang, L., Ong, J.C., Liu, Z., Dodsworth, J.A., Ahmed, R., Williams, A.J., Briggs, B.R., Liu, Y., Hou, W., and Dong, H. (2015) Isolation of diverse members of the Aquificales from geothermal springs in Tengchong, China. Front Microbiol 6, doi:10.3389/ fmicb.2015.00157.

Heine, M. and Chandra, S.B.C. (2009) The linkage between reverse gyrase and hyperthermophiles: a review of their invariable association. J Microbiol 47:229-234. 
Holwerda, J.G. and Hutchinson, R.W. (1968) Potash bearing evaporites in the Danakil area, Ethiopia. Econ Geol 63:124150.

Hovland, M., Kuznetsov, T., Rueslåtten, H., Kvamme, B., Johnsen, H.K., Fladmark, G.E., and Hebach, A. (2006) Subsurface precipitation of salts in supercritical seawater. Basin Res 18:221-230.

Hutchinson, R.W. and Engels, G.C. (1970) Tectonic significance of regional geology evaporite lithofacies in northeastern Ethiopia. Philos Trans $R$ Soc Lond A 267:313-329.

Hynek, B.M., Osterloo, M.K., and Kierein-Young, K.S. (2015) Late-stage formation of martian chloride salts through ponding and evaporation. Geology 43:787-790.

Hynek, B.M., Rogers, K.L., Antunovich, M., Avard, G., and Alvarado, G.E. (2018) Lack of microbial diversity in an extreme Mars analog setting: Poás Volcano, Costa Rica. Astrobiology 18:923-933.

Jerez, C.A., Chamorro, D., Peirano, I., Toledo, H., and Arredondo, R. (1988) Studies of the stress response in chemolithotrophic acidophilic bacteria. Biochem Int 17:989-1000.

Johnson, D.B and Aguilera, A, (2016) The microbiology of extremely acidic environments. In Manual of Environmental Microbiology, $4^{\text {th }}$ ed., edited by M.V. Yates, H. Cindy, C.H. Nakatsu, R.V. Miller, and S.D. Pillai, ASM Press, Washington, DC, pp 4.3.1-1-4.3.1-24.

Kempf, B. and Bremer, E. (1998) Uptake and synthesis of compatible solutes as microbial stress responses to highosmolality environments. Arch Microbiol 170:319-330.

Kurosawa, N., Itoh, Y.H., Iwai, T., Sugai, A., Uda, I., Kimura, N., Horiuchi, T., and Itoh, T. (1998) Sulfurisphaera ohwakuensis gen. nov., sp. nov., a novel extremely thermophilic acidophile of the order Sulfolobales. Int J Syst Bacteriol 48:451-456.

Lalou, C., von Nguyen, H., Faure, H., and Moreira, L. (1970) Datation par la method Uranium-Thorium des hautes niveaux de coraux de la dépression de l'Afar (Ethiopie). Rev Géo Phys Géol Dyn 12:3-8.

Langelier, W.F. and Ludwig, H.F. (1942) Graphical method for indicating the mineral character of natural waters. $J \mathrm{Am}$ Water Works Ass 34:335-352.

Lupi, L. (2009) Dancalia. L'esplorazione dell'Afar, un'avventura italiana, Istituto Geografico Militare, Tagete Edizioni, Italy.

Maguire, P.K.H., Keller, G.R., Klemperer, S.L., MacKenzie, G.D., Keranen, K., Harder, S., O'Reilly, B., Thybo, H., Asfaw, L., and Amha, M. (2006) Crustal structure of the Northern Main Ethiopian Rift from the EAGLE controlledsource survey; a snapshot of incipient lithospheric breakup. In The Afar Volcanic Province within the East African Rift System. Geol Soc Spec Publ 259:269-292.

Makris, J. and Ginzburg, A. (1987) The Afar Depression; transition between continental rifting and sea-floor spreading. Tectonophysics 141:199-214.

Mancinelli, R.L. (2015) The affect of the space environment on the survival of Halorubrum chaoviator and Synechococcus (Nägeli): data from the Space Experiment OSMO on EXPOSE-R. Int J Astrobiol 14:123-128.

Martin, W., Baross, J., Kelley, D., and Russell, M.J. (2008) Hydrothermal vents and the origin of life. Nat Rev Microbiol 6:805-814.

Martini, M. (1969) La geochimica del Lago Giulietti. Rend Soc Ital Mineral Petrol 25:67-78.

Martins, Z., Cottin, H., Kotler, J.M., Carrasco, N., Cockell, C.S., de la Torre Noetzel, R., Demets, R., De Vera, J.P., D'Hendecourt, L., Ehrenfreund, P., Elsaesser, A., Foing, B.,
Onofri, S., Quinn, R., Rabbow, E., Rettberg, P., Ricco, A.J., Slenzka, K., Stalport, F., Ten Kate, I.L., Van Loon, J.J.W.A., and Westall, F. (2017) Earth as a tool for astrobiology-a European perspective. Space Sci Rev 209:43-81.

Master, S. (2016) Gaet'ale- a reactivated thermal spring and potential tourist hazard in the Asale salt flats, Danakil Depression, Ethiopia. J Appl Volcanol 5:1-9, doi:10.1186/ s13617-015-0042-x.

McClusky, S., Reilinger, R., Ogubazghi, G., Amleson, A., Healeb, B., Vernant, P., Sholan, J., Fisseha, S., Asfaw, L., Bendick, R., and Kogan, L. (2010) Kinematicsofthe Southern Red Sea-Afar Triple Junction and implications for plate dynamics. Geophys Res Lett 37:L05301.

McKenzie, D.P., Davies, D., and Molnar, P. (1970) Plate tectonics of the Red Sea and East Africa. Nature 226:243-248.

Mesbah, N.M. and Wiegel, J. (2012) Life under multiple extreme conditions: diversity and physiology of the halophilic alkalithermophiles. Appl Environ Microbiol 78:4074-4082.

Michalski, J.R., Noe Dobrea, E.Z., Niles, P.B., and Cuadros, J. (2017) Ancient hydrothermal seafloor deposits in Eridania basin on Mars. Nat Commun 8:15978.

Michels, M. and Bakker, E.P. (1985) Generation of a large, protonophore-sensitive proton motive force and $\mathrm{pH}$ difference in the acidophilic bacteria Thermoplasma acidophilum and Bacillus acidocaldarius. J Bacteriol 161:231237.

Mitchell, D.J.W., Allen, R.B., Salama, W., and Abouzakm, A. (1992) Tectonostratigraphic framework and hydrocarbon potential of the Red Sea. J Petrol Geol 15:187-210.

Nisbet, E.G. and Fowler, C.M.R. (1996) Early life-some liked it hot. Nature 382:404-405.

Nobile, A., Pagli, C., Keir, D., Wright, T.J., Ayele, A., Ruch, J., and Acocella, V. (2012) Dyke-fault interaction during the 2004 Dallol intrusion at the northern edge of the Erta Ale Ridge (Afar, Ethiopia). Geophys Res Lett 39:L19305.

Ogubazghi, G., Ghebreab, W., and Havskov, J. (2004) Some features of the 1993 Bada earthquake swarm of southeastern Eritrea. J Afr Earth Sci 38:135-143.

Oren, A. (2006) Life at high salt concentrations. In The Prokaryotes, edited by E. Rosenberg, E.F. DeLong, S. Lory, E. Stackebrandt, and F. Thompson, Springer, New York, pp 263-282.

Pagli, C., Wright, T.J., Ebinger, C.J., Yun, S., Cann, J.R., Barnie, T., and Ayele, A. (2012) Shallow axial magma chamber at the slow spreading Erta Ale Ridge. Nat Geosci 5: 284-288.

PEC Engineering Division Mine. (1984) Dallol Potash Project, Phase 1A Report for Elmico, Volume 1, EMC-1A-00-1-002 (Rev 1), pp 123.

PEC Engineering Division Mine. (1986) Dallol Potash Project, Phase $1 \mathrm{AK}$ Report for Elmico, Kainite Member-Open Pit Area, EMC-40-00-1-001 (Rev 0), pp 80.

Pedgley, D.E. (1967) Air temperature at Dallol, Ethiopia. Meteorol Mag 96:265-271.

Pondrelli, M., Rossi, A.P., Le Deit, L., Fueten, F., van Gasselt, S., Glamoclija, M., Cavalazzi, B., Hauber, E., Franchi, F., and Pozzobon, R. (2015) Equatorial layered deposits in Arabia Terra, Mars: facies and process variability. Geol Soc Am Bull 127:1064-1089.

Ralph M. Parsons Company. (1966) Danakil Project Ethiopia, graphic geologic Log, Jenkins Shaft, Drawing No 1996-1-21, Los Angeles.

Redfield, T.F., Wheeler, W.H., and Often, M. (2003) A kinematic model for the development of the Afar depression and 
its paleogeographic implications. Earth Planet Sci Lett 216: 383-398.

Rodríguez, A. and van Bergen, M.J. (2016) Volcanic hydrothermal systems as potential analogues of martian sulphate-rich terrains. Neth J Geosci 95:153-169.

Rossi, A.P., Neukum, G., Pondrelli, M., van Gasselt, S., Zegers, T., Hauber, E., Chicarro, A.F., and Foing, B. (2008) Largescale spring deposits on Mars? J Geophys Res Planets 113, doi:10.1029/2007JE003062.

Rothschild, L.J. and Mancinelli, R.L. (2001) Life in extreme environments. Nature 409:1092-10101.

Ruff, S.W. and Farmer, J.D. (2016) Silica deposits on Mars with features resembling hot spring biosignatures at El Tatio in Chile. Nat Commun 7:13554.

Ruff, S.W., Farmer, J.D., Calvin, W.M., Herkenhoff, K.E., Johnson, J.R., Morris, R.V., Rice, M.S., Arvidson, R.E., Bell, J.F., III, Christensen, P.R., and Squyres, S.W. (2011) Characteristics, distribution, origin, and significance of opaline silica observed by the Spirit rover in Gusev Crater, Mars. $J$ Geophys Res 116, doi:10.1029/2010JE003767.

Russell, M.J., Hall, A.J., and Martin, W. (2010) Serpentinization as a source of energy at the origin of life. Geobiology 8: $355-371$.

Russell, M.J., Barge L.M., Bhartia, L.M., Bocanegra, D., Bracher, P.J., Branscomb, E., Kidd, R., McGlynn, S., Meier D.H., Nitschke, W., Shibuya, T., Vance, S., White, L., and Kanik, I. (2014) The drive to life on wet and icy worlds. Astrobiology 14:308-343.

Saito, M.A., Sigman, D.M., and Morel, F.M.M. (2003) The bioinorganic chemistry of the ancient ocean: the co-evolution of cyanobacterial metal requirements and biogeochemical cycles at the Archean-Proterozoic boundary. Inorg Chim Acta 356:308-318.

Santos, H. and da Costa, M.S. (2001) Organic solutes from thermophiles and hyperthermophiles. Hyperthermophilic Enzymes Part C 334:302-315.

Schlee, S., Groemping, Y., Herde, P., Seidel, R., and Reinstein, J. (2001) The chaperone function of ClpB from Thermus thermophilus depends on allosteric interactions of its two ATP-binding sites. J Mol Biol 306:889-899.

Schleper, C., Puehler, G., Holz, I., Gambacorta, A., Janekovic, D., Santarius, U., Klenk, H.P., and Zillig, W (1995) Picrophilus gen. nov. fam. nov.: a novel aerobic, heterotrophic, thermoacidophilic genus and family comprising archaea capable of growth around pH 0. J Bacteriol 177: 7050-7059.

Schofield, N., Alsop, I., Warren, J., Underhill, J.R., Lehné, R., Beer, W., and Lukas, V. (2014) Mobilizing salt: magma-salt interactions. Geology 42:599-602.

Schubert, B.A., Lowenstein, T.K., Timofeeff, M.N., and Parker, M.A. (2010) Halophilic archaea cultured from ancient halite, Death Valley, California. Environ Microbiol 12:440-454.

Schulze-Makuch, D., Dohm, J.M., Fan, C., Fairén, A.G., Rodriguez, J.A.P., Baker, V.R., and Fink, W. (2007) Exploration of hydrothermal targets on Mars. Icarus 189:308-324.

Segerer, A., Langworthy, T.A., and Stetter, K.O. (1998) Thermoplasma acidophilum and Thermoplasma volcanium sp. nov. from Solfatara field. Syst Appl Microbiol 10:161171.

Siebert, L., Simkin, T., and Kimberly, P. (2010) Volcanoes of the World, $3^{\text {rd }}$ ed., University of California Press, Berkeley.

Simmons, S. and Norris, P.R. (2002) Acidophiles of saline water at thermal vents of Volcano, Italy. Extremophiles 6: 201-207.
Simmons, S.F., White, N.C., and John, D.A. (2005) Geologic characteristics of epithermal precious and base metal deposit. Econ Geol 100:485-522.

Smewing, J.D. and McKeon, J.A. (1989) Hydrocarbon Prospectivity of the Danakil Concession, North East Ethiopia, International Petroleum Limited, Africa.

Squyres, S.W. and Knoll, A.H. (2005) Sedimentary rocks at Meridiani Planum: origin, diagenesis, and implications for life on Mars. Earth Planet Sci Lett 240:1-10.

Squyres, S.W., Arvidson, R.E., Ruff, S., Gellert, R., Morris, R.V., Ming, D.W., Crumpler, L., Farmer, J., Des Marais, D.J., Yen, A., McLennan, S.M., Calvin, W., Bell, J.F., Clark, B.C., Wang, A., McCoy, T.J., Schmidt, M.E., and De Souza, P.A. (2008) Detection of silica-rich deposits on Mars. Science 320: $1063-1067$.

Stetter, K.O. (1999) Extremophiles and their adaptation to hot environments. FEBS Lett 452:22-25.

Stivaletta, N., Barbieri, R., and Billi, D. (2012) Microbial colonization of the salt deposits in the driest place of the Atacama Desert (Chile). Orig Life Evol Biosph 42:187-200.

Stoertz, G.E. and Ericksen, G.E. (1974) Geology of Salars in Northern Chile, Geological Survey Professional Paper 811, US Government Printing Office, Washington, DC.

Suzuki, I., Lee, D., Mackay, B., Harahuc, L., and Oh, J.K. (1999) Effect of various ions, $\mathrm{pH}$, and osmotic pressure on oxidation of elemental sulfur by Thiobacillus thiooxidans. Appl Environ Microbiol 65:5163-5168.

Talbot, C.J. (2008) Hydrothermal salt—but how much? Mar Pet Geol 25:191-202.

Talbot, C.J., Stanley, W., Soub, R., and Al-Sadoun, N. (1996) Epitaxial salt reefs and mushrooms in the southern Dead Sea. Sedimentology 43:1025-1047.

Tazieff, H., Marinelli, G., Barberi, F., and Varet, J. (1969) Géologie de l'Afar septentrional Symposium Ass. Interna. Volcanologie, Canaries. Bull Volc XXXIII-4:1039-1072.

Tesfaye, S., Harding, D.J., and Kusky, T.M. (2003) Early continental breakup boundary and migration of the Afar triple junction, Ethiopia. Geol Soc Am Bull 115:1053-1067.

Teske, A. (2009) Deep-sea hydrothermal vents. In Desk Encyclopedia of Microbiology, edited by M. Schaechter, Elsevier, Amsterdam, pp 346-356.

Thurmond, A.K., Abdelsalam, M.G., and Thurmond, J.B. (2006) Optical radar-DEM remote sensing data integration for geological mapping in the Afar Depression, Ethiopia. $J$ Afr Earth Sci 44:119-134.

Vago, J.L., editor. (2017) Special collection of papers: ExoMars rover mission. Astrobiology 17:471-685.

Varet, J. (2018) Geology of Afar (East Africa), Springer International Publishing, Cham, Switzerland.

Ventosa, A., De la Haba, R.R., Sánchez-Porro, C., and Papke, R.T. (2015) Microbial diversity of hypersaline environments: a metagenomic approach. Curr Opin Microbiol 25: 80-87.

Vieille, C. and Zeikus, G.J. (2001) Hyperthermophilic enzymes: sources, uses, and molecular mechanisms for thermostability. Microbiol Mol Biol Rev 65:1-43.

Vreeland, R.H. (1987) Mechanisms of halotolerance in microorgnanisms. CRC Crit Rev Microbiol 14:311-356.

Vreeland, R.H., Rosenzweig, W.D., and Powers, D.W. (2000) Isolation of a 250 million-year-old halotolerant bacterium from a primary salt crystal. Nature 407:897-900.

Vreeland, R.H., Jones, J., Monson, A., Rosenzweig, W.D., Lowenstein, T.K., Timofeeff, M., Satterfield, C., Cho B.C., Park, J.S., Wallace, A., and Grant, W.D. (2007) Isolation of 
live Cretaceous (121-112 million years old) halophilic archaea from primary salt crystals. Geomicrobiol J 24:275-282.

Walter, M.R. and Des Marais, D.J. (1993) Preservation of biological information in thermal spring deposits: developing a strategy for the search for fossil life on Mars. Icarus 101:129-143.

Warren, J.K. (2016) Evaporites: A Geological Compendium, Springer International Publishing, Cham, Switzerland.

White, T.D., Suwa, G., and Asfaw, B. (1994) Australopithecus ramidus, a new species of early hominid from Aramis, Ethiopia. Nature 371:306-312.

Wood, B.A. (1994) Evolution of australopithecines. In The Cambridge Encyclopedia of Human Evolution, edited by S. Jones, R. Martin, and D. Pilbeam, Cambridge University Press, Cambridge, UK, pp 231-240.

Wright, T.J., Ebinger, C., Biggs, J., Ayele, A., Yirgu, Y., Keir, D., and Stork, A. (2006) Magma maintained rift segmentation at continental rupture in the 2005 Afar dyking episode. Nature 442:291-294.

Zabrusky, K., Andrews-Hanna, J.C., and Wiseman, S.M. (2012) Reconstructing the distribution and depositional history of the sedimentary deposits of Arabia Terra, Mars. Icarus 220:311-330.
Address correspondence to: Barbara Cavalazzi

Dipartimento di Scienze Biologiche, Geologiche e Ambientali - BiGeA

Università di Bologna

Via Zamboni 67

I-40126 Bologna

Italy

E-mail: barbara.cavalazzi@unibo.it

Submitted 26 June 2018

Accepted 28 September 2018

Associate Editor: Jack Mustard

\section{Abbreviations Used \\ a.s.l. $=$ above sea level \\ b.s.l. = below sea level}

